\title{
The Historical/Evolutionary Cause and Possible Treatment of Pandemic COVID-19 (SARS-CoV-2, 2019-Coronavirus)
}

\begin{abstract}
Niknamian $S^{*}$
Associate Professor of Medicine, John D Dingell VA Medical Center and Wayne State University, USA
\end{abstract}

*Corresponding author: Sorush Niknamian, Chief, Division of Infectious Diseases, John D Dingell VA Medical Center, Associate Professor of Medicine, Wayne State University Detroit, MI USA, Tel: 313-576-3057; Fax: 313-576-1242; Email: so.niknamian@gmail.com

\section{Review Article}

Volume 3 Issue 1

Received Date: May 02, 2020

Published Date: June 15, 2020

DOI: $10.23880 /$ oajmms-16000123

\section{Abstract}

Background: A virus is a small infectious agent that replicates only inside the living cells of an organism. Viruses can infect all types of life forms, from animals and plants to microorganisms, including bacteria and archaea. In evolution, viruses are an important means of horizontal gene transfer, which increases genetic diversity in a way analogous to sexual reproduction. Influenza (Including (COVID-19), is an infectious disease caused by an influenza virus. Some viruses especially smallpox, throughout history, has killed between 300-500 million people in its 12,000year existence. As modern humans increased in numbers, new infectious diseases emerged, including SARS-CoV-2. We have two groups of virus, RNA and DNA viruses. The most brutal viruses are RNA ones like COVID-19 Sars-CoV-2. Introduction: Coronaviruses are a group of viruses that cause diseases in mammals and birds. In humans, coronaviruses cause respiratory tract infections that are typically mild, such as some cases of the common cold (among other possible causes, predominantly rhinoviruses), though rarer forms can be lethal, such as SARS, MERS, and COVID-19. Symptoms vary in other species: in chickens, they cause an upper respiratory tract disease, while in cows and pigs they cause diarrhea. Coronaviruses constitute the subfamily Orthocoronavirinae, The genome size, coronaviruses ranges from approximately 27 to 34kilobases, the largest among known RNA viruses.

Discussions and Results: We have researched from the first virus in the planet to the last mutated version which is SARS-COV-2. We have collected many informative data in tables and figures to reach the main cause of 2019-Coronavirus and calculated the probability and estimated deaths in the current time. We have discussed about the possible treatment and prevention of the virus and did algebraic calculations on the epidemiology, the size and even the future of this pandemic. The only era which any virus had not been epidemic, were through world war 2 , were the German scientists had found the way to fight any viral infections which is very important and can help scientists to reach the main treatment of the new 2019-Coronavirus. We have sorted the deadly and non-deadly coronaviruses and explained how this epidemic had begun through Evolutionary Medicine (EM). The result of the article is that $16 \%$ of the whole population in the world has been contaminated which is 1248000000 of $7.8 \mathrm{billion}$ people world-wide. SARS-CoV-2 is an RNA virus. Its nucleic acid is single-stranded RNA (ssRNA). The polarity of this virus is positive-sense $((+)$ ssRNA). Positive-sense viral RNA is similar to mRNA and thus can be immediately translated by the host cell. Recombination in RNA viruses appears to be an adaptation for coping with genome damage. Recombination can occur infrequently between animal viruses of the same species but of divergent lineages. The resulting recombinant viruses may sometimes cause an outbreak of infection in humans. RNA viruses have very 


\section{Open Access Journal of Mycology \& Mycological Sciences}

high mutation rates this is one reason why it is difficult to make effective vaccines to prevent diseases caused by RNA viruses. The resulting recombinant viruses cause an outbreak of infection in humans.

Conclusion: In conclusion, the mutation of the SARS-CoV and influenza viruses through Drift and Reassortment is the main cause of SARS-CoV-2 through natural selection, Lamarckian Evolution and coevolution which caused this RNA virus so powerful, unpredicted and different in the genome size and nations worldwide. The first Pandemic of Influenza was first detected in 1732 and this virus evolved through natural selection till 2019 which caused the worldwide pandemic of SARS-CoV-2. Based on many studies, inhalation of Ozone plus Sulfur Dioxide, increasing the amounts of L-Glutathione (Which is low in children and older adults and this is the main reason why older adults and children die from this disease.) plus Viral Phage Therapy (VPT) which we discussed fully in this article can be the possible prime treatment of SARS-CoV-2 infection. The seasonal temperature cannot be useful in controlling/ reducing the pandemic of this virus since the natural selection, Lamarckian Evolution and high mutation of the virus helps its survival. No antiviral drugs will be useful against SARS-CoV-2 because of high rate of mutation and primarily adaptation of the virus to the drugs and even the environmental Temperature.

Keywords: COVID-19(SARS-CoV-2); Positive-Sense((+)ssRNA); Viral Phage Therapy; Sulfur Dioxide; Ozone; Influenza; Natural Selection; Lamarckian Evolution; Fibonacci Series; L-Glutathione; Drift; Reassortment; Pandemic

Abbreviations: EM: Evolutionary Medicine; VPT: Viral Phage Therapy; MRCA: Most Recent Common Ancestor; VSV: Vesicular Stomatitis Virus; SARS: Severe Acute Respiratory Syndrome; WAPF: Weston A Price Foundation.

\section{Introduction}

\section{Brief History of Viruses}

Prehistory: The world, new infectious diseases emerged, including those caused by viruses [1]. Earlier, humans lived in small, isolated communities, and most epidemic diseases did not exist. Smallpox, which is the most lethal and devastating viral infection in history [2,3], first emerged among agricultural communities in India about 11,000 years ago [4]. The virus, which only infected humans, probably descended from the poxviruses of rodents [5]. Humans probably came into contact with these rodents, and some people became infected by the viruses they carried. When viruses cross this so-called "species barrier", their effects can be severe [6], and humans may have had little natural resistance. Contemporary humans lived in small communities, and those who succumbed to infection either died or developed immunity. This acquired immunity is only passed down to offspring temporarily, by antibodies in breast milk and other antibodies that cross the placenta from the mother's blood to the unborn child's. Therefore, sporadic outbreaks probably occurred in each generation. In about 9000BC, when many people began to settle on the fertile flood plains of the River Nile, the population became dense enough for the virus to maintain a constant presence because of the high concentration of susceptible people [7]. Other epidemics of viral diseases that depend on large concentrations of people, such as mumps, rubella and polio, also first occurred at this time [8]. The Neolithic age, which began in the Middle East in about $9500 \mathrm{BC}$, was a time when humans became farmers [9]. This agricultural revolution embraced the development of monoculture and presented an opportunity for the rapid spread of several species of plant viruses [10]. The divergence and spread of sobemoviruses-southern bean mosaic virusdate from this time [11]. The spread of the pot viruses of potatoes, and other fruits and vegetables, began about 6,600 years ago [10]. About 10,000 years ago the humans who inhabited the lands around the Mediterranean basin began to domesticate wild animals. Pigs, cattle, goats, sheep, horses, camels, cats and dogs were all kept and bred in captivity [12]. These animals would have brought their viruses with them [13]. The transmission of viruses from animals to humans can occur, but such zoonotic infections are rare and subsequent human-to-human transmission of animal viruses is even rarer, although there are notable exceptions such as influenza. Most viruses are species-specific and would have posed no threat to humans [14]. The rare epidemics of viral diseases originating in animals would have been short-lived because the viruses were not fully adapted to humans [15] and the human populations were too small to maintain the chains of infection [16]. Other, more ancient, viruses have been less of a threat. Herpes viruses first infected the ancestors of modern humans over 80 million years ago [17]. Humans have developed a tolerance to these viruses, and most are infected with at least one species [18]. Records of these milder virus infections are rare, but it is likely that early hominids suffered from colds, influenza and diarrhoea caused by viruses just as humans do today. More recently evolved viruses cause epidemics and pandemics [17]. The influenza virus is one that seems to have crossed the species barrier from ducks and water fowl to pigs and from there to 
humans. It is possible that a fatal plague in the Middle East at the time of the late 18th Dynasty was associated with this transmission at Amarna $[19,20]$.

Influenza: Influenza, commonly known as the flu, is an infectious disease caused by an influenza virus [21]. Symptoms can be mild to severe. The most common symptoms include: high fever, runny nose, sore throat, muscle and joint pain, headache, coughing, and feeling tired just like SarsCoV-2 [21]. These symptoms typically begin two days after exposure to the virus and most last less than a week [21]. The cough, however, may last for more than two weeks [21]. In children, there may be diarrhea and vomiting, but these are not common in adults [22]. Diarrhea and vomiting occur more commonly in gastroenteritis, which is an unrelated disease and sometimes inaccurately referred to as stomach flu or the 24-hour flu [22]. Complications of influenza may include viral pneumonia, secondary bacterial pneumonia, sinus infections, and worsening of previous health problems such as asthma or heart failure [22,23]. Three of the four types of influenza viruses affect humans: Type A, Type B, and Type C $[22,24]$ Type D has not been known to infect humans, but is believed to have the potential to do so [25,26]. Usually, the virus is spread through the air from coughs or sneezes [21]. This is believed to occur mostly over relatively short distances [27]. It can also be spread by touching surfaces contaminated by the virus and then touching the eyes, nose, or mouth [28-30]. A person may be infectious to others both before and during the time they are showing symptoms. The infection may be confirmed by testing the throat, sputum, or nose for the virus. A number of rapid tests are available; however, people may still have the infection even if the results are negative. A type of polymerase chain reaction that detects the virus's RNA is more accurate [22] (Figures 1-4).

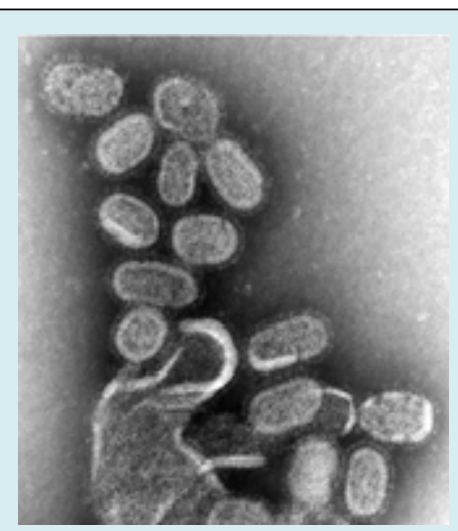

Figure 1: Influenza virus magnified approximately 100,000 times, Specialty: Infectious disease. Symptoms: Fever, runny nose, sore throat, muscle and joint pain, headache, coughing, feeling tired, Usual onset: One to four days after exposure, Duration: 1 week, Causes: Influenza viruses.

Prevention: Hand washing, influenza vaccine, surgical masks, Frequency: 3-5million severe cases per year. Deaths: Up to 650,000 respiratory deaths per year [1-3] (Table 1).

\begin{tabular}{|c|c|c|}
\hline Symptom & Sensitivity & Specificity \\
\hline Fever & $68-86 \%$ & $25-73 \%$ \\
\hline Cough & $84-98 \%$ & $7-29 \%$ \\
\hline Nasal congestion & $68-91 \%$ & $19-41 \%$ \\
\hline All three findings, especially fever, were less sensitive in people over 60 years of age. & & \\
\hline
\end{tabular}

Table 1: Most sensitive symptoms for diagnosing influenza [1-3].

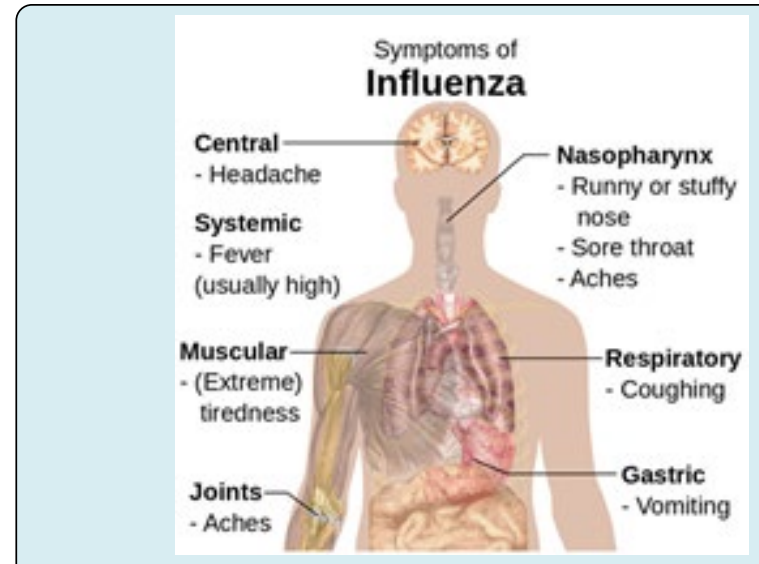

Figure 2: Symptoms of influenza, with fever and cough the most common symptoms [20-22].

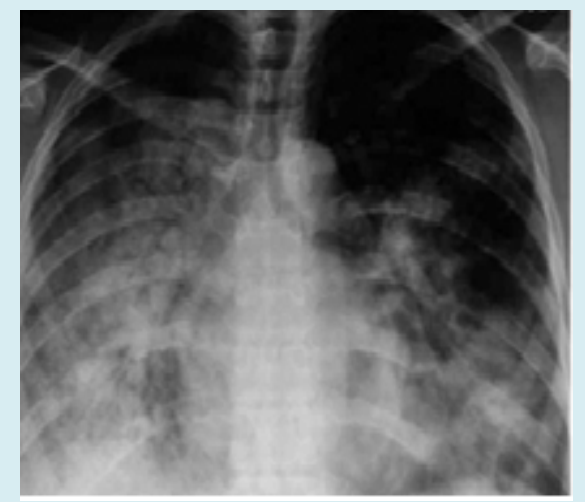

Figure 3: 29 years old with H1N1 with high inflammation in the lungs and respiratory systems. 


\section{Open Access Journal of Mycology \& Mycological Sciences}

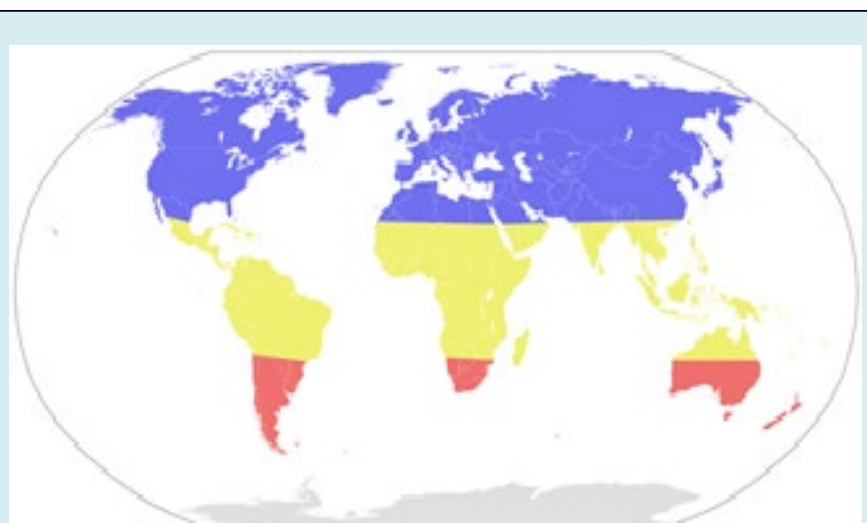

Figure 4: Seasonal risk areas for influenza: November-April (blue), April-November (red), and year-round (yellow) [21].

List of Epidemics of Plagues (Tables 2-6)

\begin{tabular}{|c|c|c|c|c|}
\hline Death Toll (Estimate) & Location & Date & Event & Disease \\
\hline $75,000-100,000$ & Greece & $429-426 \mathrm{BC}$ & Plague of Athens & $\begin{array}{l}\text { Unknown, possibly typhus, } \\
\text { typhoid fever or viral } \\
\text { hemorrhagic fever }\end{array}$ \\
\hline \multirow[t]{2}{*}{ 5-10 million } & Roman Empire & $\begin{array}{c}165-180 \\
\text { (possibly up to } \\
190 \text { ) }\end{array}$ & Antonine Plague & Unknown, possibly smallpox \\
\hline & Europe & $250-266$ & Plague of Cyprian & Unknown, possibly smallpox \\
\hline \multicolumn{3}{|c|}{$\begin{array}{c}25-50 \text { million; } 40 \% \text { of population } \\
\text { Europe, Egypt and West Asia } \\
541-542\end{array}$} & Plague of Justinian & Plague \\
\hline & Rome & 590 & Roman Plague of 590 & Plague \\
\hline \multirow[t]{4}{*}{$>100,000$} & Ctesiphon, Persia & $627-628$ & Plague of Sheroe & Plague \\
\hline & British Isles & $664-689$ & Plague of 664 & Plague \\
\hline & Japan & $735-737$ & $\begin{array}{l}\text { 735-737 Japanese } \\
\text { smallpox epidemic }\end{array}$ & Smallpox \\
\hline & $\begin{array}{l}\text { Byzantine Empire, } \\
\text { West Asia, Africa }\end{array}$ & $746-747$ & Plague of $746-747$ & Plague \\
\hline $\begin{array}{l}20-00 \text { million; } 20-60 \% \\
\text { of European population }\end{array}$ & $\begin{array}{l}\text { Europe, Asia and } \\
\text { North Africa }\end{array}$ & $1331-1353$ & Black Death & Plague Y. pestis \\
\hline$>10,000$ & $\begin{array}{l}\text { England and later } \\
\text { continental Europe }\end{array}$ & $1485-1551$ & $\begin{array}{l}\text { Sweating sickness } \\
\text { (multiple outbreaks) }\end{array}$ & $\begin{array}{l}\text { Unknown, possibly an } \\
\text { unknown species of hantavirus }\end{array}$ \\
\hline
\end{tabular}

Table 2: $15^{\text {th }}$ century and earlier. 


\section{Open Access Journal of Mycology \& Mycological Sciences}

\begin{tabular}{|c|c|c|c|c|c|}
\hline $\begin{array}{l}\text { Death Toll } \\
\text { (Estimate) }\end{array}$ & Location & Date & Event & Disease & Ref. \\
\hline & Canada, New France & $1702-1703$ & & Smallpox & [31] \\
\hline $\begin{array}{l}>18,000(36 \% \\
\text { of population) }\end{array}$ & Iceland & $1707-1709$ & Great Smallpox Epidemic & Smallpox & \\
\hline & Denmark, Sweden & $1710-1712$ & $\begin{array}{l}\text { Great Northern War } \\
\text { plague outbreak }\end{array}$ & Plague & \\
\hline & Thirteen Colonies & $1713-1715$ & & Measles & [32] \\
\hline & Canada, New France & $1714-1715$ & & Measles & [33] \\
\hline & France & $1720-1722$ & Great Plague of Marseille & Plague & [34] \\
\hline & Thirteen Colonies & $1721-1722$ & & Smallpox & [35] \\
\hline & Thirteen Colonies & 1729 & & Measles & [36] \\
\hline & Spain & 1730 & & Yellow fever & \\
\hline & Thirteen Colonies & $1732-1733$ & & Influenza & [37] \\
\hline & Canada, New France & 1733 & & Smallpox & [38] \\
\hline & Balkans & 1738 & Great Plague of 1738 & Plague & \\
\hline \multirow{8}{*}{$>50,000$} & Thirteen Colonies & 1738 & & Smallpox & [39] \\
\hline & Thirteen Colonies & $1739-1740$ & & Measles & \\
\hline & Italy & 1743 & & Plague & [40] \\
\hline & Thirteen Colonies & 1747 & & Measles & \\
\hline & North America & $1755-1756$ & & Smallpox & \\
\hline & North America & 1759 & & Measles & [41] \\
\hline & North America, West Indies & 1761 & & Influenza & \\
\hline & $\begin{array}{c}\text { North America, present-day } \\
\text { Pittsburgh area. }\end{array}$ & 1763 & & Smallpox & [42] \\
\hline \multirow[t]{3}{*}{$>50,000$} & Russia & $1770-1772$ & $\begin{array}{l}\text { Russian plague of } 1770- \\
1772 \\
\end{array}$ & Plague & \\
\hline & Pacific Northwest natives & $1770 \mathrm{~s}$ & & Smallpox & [43] \\
\hline & North America & 1772 & & Measles & \\
\hline \multirow[t]{9}{*}{$>2,000,000$} & Persia & 1772 & 1772 Persia plague & Plague & [44] \\
\hline & England & $1775-1776$ & & Influenza & [45] \\
\hline & Spain & 1778 & & Dengue fever & [46] \\
\hline & Plains Indians & $1780-1782$ & $\begin{array}{c}\text { North American } \\
\text { smallpox epidemic }\end{array}$ & Smallpox & [47] \\
\hline & Pueblo Indians & 1788 & & Smallpox & [48] \\
\hline & United States & 1788 & & Measles & \\
\hline & New South Wales, Australia & $1789-1790$ & & Smallpox & [49] \\
\hline & United States & 1793 & & $\begin{array}{c}\text { Influenza and } \\
\text { Epidemic Typhus }\end{array}$ & \\
\hline & United States & $1793-1798$ & $\begin{array}{l}\text { Yellow Fever Epidemic of } \\
1793 \text {, resurgences }\end{array}$ & Yellow fever & [50] \\
\hline
\end{tabular}

Table 3: $18^{\text {th }}$ Century. 


\section{Open Access Journal of Mycology \& Mycological Sciences}

\begin{tabular}{|c|c|c|c|c|c|}
\hline $\begin{array}{l}\text { Death toll } \\
\text { (estimate) }\end{array}$ & Location & Date & Event & Disease & Ref. \\
\hline $1,000,000$ & Russia & $1852-1860$ & Third cholera pandemic & Cholera & [88] \\
\hline $1,000,000$ & Worldwide & $1889-1890$ & $\begin{array}{c}1889-1890 \mathrm{flu} \\
\text { pandemic }\end{array}$ & Influenza & [83] \\
\hline$>100,000$ & Asia, Europe & $1816-1826$ & First cholera pandemic & Cholera & [89] \\
\hline$>100,000$ & Asia, Europe, North America & $1829-1851$ & $\begin{array}{c}\text { Second cholera } \\
\text { pandemic }\end{array}$ & Cholera & [89] \\
\hline 40,000 & Fiji & 1875 & $\begin{array}{c}1875 \text { Fiji Measles } \\
\text { outbreak }\end{array}$ & Measles & {$[81]$} \\
\hline$>20,000$ & Canada & $1847-1848$ & $\begin{array}{c}\text { Typhus epidemic of } \\
1847\end{array}$ & Epidemic typhus & [69] \\
\hline$>9,000$ & India, Germany & $1881-1896$ & Fifth cholera pandemic & Cholera & [89] \\
\hline 4,737 & Copenhagen, Denmark & 1853 & $\begin{array}{c}\text { Cholera epidemic of } \\
\text { Copenhagen } 1853\end{array}$ & Cholera & [73] \\
\hline 3,164 & Montreal & 1885 & & Smallpox & timeline \\
\hline$>3,000$ & Central Coast, British Columbia & $1862-1863$ & & Smallpox & [78] \\
\hline \multirow[t]{24}{*}{616} & England & 1854 & $\begin{array}{c}\text { Broad Street cholera } \\
\text { outbreak }\end{array}$ & Cholera & {$[74]$} \\
\hline & Spain & $1800-1803$ & & Yellow fever & [86] \\
\hline & Ottoman Empire, Egypt & 1801 & & Bubonic plague & [87] \\
\hline & United States & 1803 & & Yellow fever & \\
\hline & Egypt & 1812 & & Plague & \\
\hline & Ottoman Empire & 1812 & & Plague & [88] \\
\hline & Malta & 1813 & & Plague & \\
\hline & Romania & 1813 & Caragea's plague & Plague & \\
\hline & Ireland & $1816-1819$ & & Typhus & \\
\hline & United States & $1820-1823$ & & Yellow fever & \\
\hline & Spain & 1821 & & Yellow fever & {$[90]$} \\
\hline & New South Wales, Australia & 1828 & & Smallpox & [91] \\
\hline & Netherlands & 1829 & Groningen epidemic & Malaria & \\
\hline & South Australia & 1829 & & Smallpox & [92] \\
\hline & Iran & 1829-1835 & & Bubonic plague & [93] \\
\hline & Egypt & 1831 & & Cholera & [94][95] \\
\hline & Plains Indians & $1831-1834$ & & Smallpox & \\
\hline & England, France & 1832 & & Cholera & \\
\hline & North America & 1832 & & Cholera & [96] \\
\hline & United States & 1833 & & Cholera & \\
\hline & United States & 1834 & & Cholera & \\
\hline & Egypt & $1834-1836$ & & Bubonic plague & [96][97] \\
\hline & United States & 1837 & & Typhus & \\
\hline & Great Plains & $1837-1838$ & $\begin{array}{c}\text { 1837-38 smallpox } \\
\text { epidemic }\end{array}$ & Smallpox & [98] \\
\hline
\end{tabular}




\section{Open Access Journal of Mycology \& Mycological Sciences}

\begin{tabular}{|c|c|c|c|c|}
\hline Dalmatia & 1840 & & Plague & \\
\hline South Africa & 1840 & & Smallpox & \\
\hline United States & 1841 & & Yellow fever & \\
\hline United States & 1847 & & Yellow fever & \\
\hline Worldwide & $1847-1848$ & & Influenza & [99] \\
\hline Egypt & 1848 & & Cholera & [96][97] \\
\hline North America & $1848-1849$ & & Cholera & \\
\hline United States & 1850 & & Yellow fever & \\
\hline North America & $1850-1851$ & & Influenza & \\
\hline United States & 1851 & & Cholera & [100] \\
\hline United States & 1852 & & Yellow fever & \\
\hline Ottoman Empire & 1853 & & Plague & [101] \\
\hline United States & 1855 & & Yellow fever & \\
\hline Worldwide & $1855-1960$ & Third plague pandemic & Bubonic plague & [102] \\
\hline Portugal & 1857 & & Yellow fever & \\
\hline Victoria, Australia & 1857 & & Smallpox & [103] \\
\hline $\begin{array}{c}\text { Europe, North America, South } \\
\text { America }\end{array}$ & $1857-1859$ & & Influenza & [104] \\
\hline Middle East & $1863-1879$ & $\begin{array}{l}\text { Fourth cholera } \\
\text { pandemic }\end{array}$ & Cholera & [112]] \\
\hline Egypt & 1865 & & Cholera & [96][97] \\
\hline Russia, Germany & $1866-1867$ & & Cholera & \\
\hline Australia & 1867 & & Measles & \\
\hline Iraq & 1867 & & Plague & [105] \\
\hline Argentina & $1852-1871$ & & Yellow fever & [106] \\
\hline Germany & $1870-1871$ & & Smallpox & \\
\hline Russian Empire & 1877 & & Plague & {$[108]$} \\
\hline Egypt & 1881 & & Cholera & [96][97] \\
\hline West Africa & 1900 & & Yellow fever & \\
\hline
\end{tabular}

Table 4: $19^{\text {th }}$ century.

\begin{tabular}{|c|c|c|c|c|c|}
\hline $\begin{array}{l}\text { Death Toll } \\
\text { (Estimate) }\end{array}$ & Location & Date & Event & Disease & Ref. \\
\hline & Congo Basin & $1896-1906$ & & Trypanosomiasis & [85] \\
\hline$>800,000$ & Europe, Asia, Africa & 1899-1923 & Sixth cholera pandemic & Cholera & {$[86]$} \\
\hline \multirow[t]{3}{*}{113} & San Francisco & $1900-1904$ & & Bubonic plague & [87] \\
\hline & Uganda & $1900-1920$ & & Trypanosomiasis & {$[88]$} \\
\hline & Egypt & 1902 & & Cholera & {$[83,84]$} \\
\hline 22 & India & 1903 & & Bubonic Plague & [89] \\
\hline 4 & Fremantle & 1903 & & Bubonic plague & {$[90]$} \\
\hline 40,000 & China & $1910-1912$ & 1910 China plague & Bubonic plague & [91] \\
\hline 1.5 million & worldwide & $1915-1926$ & $\begin{array}{l}1915 \text { Encephalitis } \\
\text { lethargica pandemic }\end{array}$ & Encephalitis lethargica & [92] \\
\hline up to $100,000,000$ & worldwide & $1918-1920$ & Spanish flu & $\begin{array}{c}\text { Influenza Spanish Flu } \\
\text { Virus }\end{array}$ & [93] \\
\hline
\end{tabular}




\section{Open Access Journal of Mycology \& Mycological Sciences}

\begin{tabular}{|c|c|c|c|c|c|}
\hline & Russia & $1918-1922$ & & Typhus & \\
\hline 30 & Los Angeles & 1924 & $\begin{array}{c}1924 \text { Los Angeles } \\
\text { pneumonic plague } \\
\text { outbreak }\end{array}$ & Pneumonic plague & \\
\hline \multirow[t]{5}{*}{43} & Croydon, UK & 1937 & $\begin{array}{l}\text { Croydon epidemic of } \\
\text { typhoid fever }\end{array}$ & Typhoid fever & [94] \\
\hline & Egypt & $1942-1944$ & & Malaria & {$[83,84]$} \\
\hline & China & 1946 & & Bubonic plague & \\
\hline & Egypt & 1946 & & Relapsing fever & {$[83,84]$} \\
\hline & Egypt & 1947 & & Cholera & {$[83,84]$} \\
\hline \multirow[t]{2}{*}{$2,000,000$} & worldwide & $1957-1958$ & Asian flu & Influenza & [95] \\
\hline & worldwide & $1961-1975$ & $\begin{array}{l}\text { Seventh cholera } \\
\text { pandemic }\end{array}$ & Cholera & {$[96]$} \\
\hline 4 & Sweden & 1963 & & Smallpox & {$[97,98]$} \\
\hline $1,000,000$ & worldwide & $1968-1969$ & Hong Kong flu & Influenza & [99] \\
\hline 5 & Netherlands & 1971 & & Poliomyelitis & [100] \\
\hline \multirow[t]{2}{*}{35} & Yugoslavia & 1972 & $\begin{array}{c}1972 \text { outbreak of } \\
\text { smallpox in Yugoslavia }\end{array}$ & Smallpox & \\
\hline & United States & $1972-1973$ & London flu & Influenza & [101] \\
\hline 15,000 & India & 1974 & $\begin{array}{c}1974 \text { smallpox epidemic } \\
\text { of India }\end{array}$ & Smallpox & {$[102]$} \\
\hline \multirow[t]{2}{*}{$>32,000,000$} & $\begin{array}{c}\text { worldwide } \\
\text { (commenced in Congo } \\
\text { Basin) }\end{array}$ & 1960-present & HIV/AIDS pandemic & HIV/AIDS & [103] \\
\hline & South America & $1990 \mathrm{~s}$ & & Cholera & \\
\hline 52 & India & 1994 & $\begin{array}{c}1994 \text { plague epidemic in } \\
\text { Surat }\end{array}$ & Plague & {$[104]$} \\
\hline \multirow[t]{2}{*}{231} & worldwide & $1996-2001$ & & $\mathrm{vCJD}$ & \\
\hline & West Africa & 1996 & & Meningitis & \\
\hline \multirow[t]{2}{*}{105} & Malaysia & 1998-1999 & $\begin{array}{c}\text { 1998-99 Malaysia Nipah } \\
\text { virus outbreak }\end{array}$ & Nipah virus infection & {$[105]$} \\
\hline & Central America & 2000 & & Dengue fever & [106] \\
\hline
\end{tabular}

Table 5: $20^{\text {th }}$ century.

\begin{tabular}{|c|c|c|c|c|c|}
\hline Death Toll (Estimate) & Location & Date & Event & Disease & Ref. \\
\hline$>400$ & Nigeria & 2001 & & Cholera & {$[107]$} \\
\hline & South Africa & 2001 & & Cholera & {$[108]$} \\
\hline 349 & China & $2002-2004$ & SARS outbreak & SARS coronavirus & {$[109]$} \\
\hline 299 & Hong Kong & $2002-2004$ & SARS outbreak & SARS coronavirus & {$[110]$} \\
\hline 37 & Taiwan & $2002-2004$ & SARS outbreak & SARS coronavirus & {$[111]$} \\
\hline 44 & Canada & $2002-2004$ & SARS outbreak & SARS coronavirus & {$[112]$} \\
\hline 33 & Singapore & $2002-2004$ & SARS outbreak & SARS coronavirus & {$[113]$} \\
\hline
\end{tabular}




\section{Open Access Journal of Mycology \& Mycological Sciences}

\begin{tabular}{|c|c|c|c|c|c|}
\hline & Algeria & 2003 & & Plague & [114] \\
\hline & Afghanistan & 2004 & & Leishmaniasis & [115] \\
\hline & Bangladesh & 2004 & & Cholera & [116] \\
\hline & Indonesia & 2004 & & Dengue fever & [117] \\
\hline & Senegal & 2004 & & Cholera & [118] \\
\hline \multirow[t]{2}{*}{7} & Sudan & 2004 & & Ebola & [119] \\
\hline & Mali & 2005 & & Yellow fever & [120] \\
\hline \multirow[t]{2}{*}{27} & Singapore & 2005 & $\begin{array}{c}2005 \text { dengue outbreak } \\
\text { in Singapore }\end{array}$ & Dengue fever & [121] \\
\hline & Luanda, Angola & 2006 & & Cholera & [122] \\
\hline 61 & $\begin{array}{l}\text { Ituri Province, } \\
\text { Democratic } \\
\text { Republic of the } \\
\text { Congo }\end{array}$ & 2006 & & Plague & {$[123,124]$} \\
\hline 17 & India & 2006 & & Malaria & [125] \\
\hline \multirow[t]{2}{*}{$>50$} & India & 2006 & $\begin{array}{c}2006 \text { dengue outbreak } \\
\text { in India }\end{array}$ & Dengue fever & [126] \\
\hline & India & 2006 & $\begin{array}{c}\text { Chikungunya } \\
\text { outbreaks }\end{array}$ & $\begin{array}{l}\text { Chikungunya } \\
\text { virus }\end{array}$ & [127] \\
\hline \multirow[t]{2}{*}{$>50$} & Pakistan & 2006 & $\begin{array}{c}2006 \text { dengue outbreak } \\
\text { in Pakistan }\end{array}$ & Dengue fever & [128] \\
\hline & Philippines & 2006 & & Dengue fever & [129] \\
\hline \multirow[t]{2}{*}{187} & $\begin{array}{c}\text { Democratic } \\
\text { Republic of the } \\
\text { Congo }\end{array}$ & 2007 & Mweka ebola epidemic & Ebola & [130] \\
\hline & Ethiopia & 2007 & & Cholera & [131] \\
\hline 49 & India & 2008 & & Cholera & [132] \\
\hline \multirow[t]{4}{*}{10} & Iraq & 2007 & $\begin{array}{c}2007 \text { Iraq cholera } \\
\text { outbreak }\end{array}$ & Cholera & [133] \\
\hline & Nigeria & 2007 & & Poliomyelitis & [134] \\
\hline & $\begin{array}{c}\text { Puerto Rico; } \\
\text { Dominican } \\
\text { Republic; Mexico }\end{array}$ & 2007 & & Dengue fever & [135] \\
\hline & Somalia & 2007 & & Cholera & [136] \\
\hline \multirow[t]{9}{*}{37} & Uganda & 2007 & & Ebola & [137] \\
\hline & Vietnam & 2007 & & Cholera & [138] \\
\hline & Brazil & 2008 & & Dengue fever & [139] \\
\hline & Cambodia & 2008 & & Dengue fever & [140] \\
\hline & Chad & 2008 & & Cholera & [141] \\
\hline & China & $2008-2017$ & & $\begin{array}{l}\text { Hand, foot and } \\
\text { mouth disease }\end{array}$ & [142] \\
\hline & Madagascar & 2008 & & Bubonic plague & [143] \\
\hline & Philippines & 2008 & & Dengue fever & [144] \\
\hline & Vietnam & 2008 & & Cholera & [145] \\
\hline
\end{tabular}




\begin{tabular}{|c|c|c|c|c|c|}
\hline 4,293 & Zimbabwe & $2008-2009$ & $\begin{array}{c}2008-2009 \\
\begin{array}{c}\text { Zimbabwean cholera } \\
\text { outbreak }\end{array} \\
\end{array}$ & Cholera & {$[146]$} \\
\hline 18 & Bolivia & 2009 & $\begin{array}{l}2009 \text { Bolivian dengue } \\
\text { fever epidemic }\end{array}$ & Dengue fever & [147] \\
\hline \multirow[t]{3}{*}{49} & India & 2009 & $\begin{array}{c}2009 \text { Gujarat hepatitis } \\
\text { outbreak }\end{array}$ & Hepatitis B & [148] \\
\hline & $\begin{array}{l}\text { Queensland, } \\
\text { Australia }\end{array}$ & 2009 & & Dengue fever & [149] \\
\hline & Worldwide & 2009 & $\begin{array}{l}\text { Mumps outbreaks in } \\
\text { the 2000s }\end{array}$ & Mumps & \\
\hline 931 & West Africa & $2009-2010$ & $\begin{array}{c}\text { 2009-2010 West } \\
\text { African meningitis } \\
\text { outbreak }\end{array}$ & Meningitis & [150] \\
\hline 203,000 & Worldwide & 2009 & 2009 flu pandemic & Influenza & {$[151,152]$} \\
\hline 9,985 (May 2017) & Hispaniola & 2010-present & Haiti cholera outbreak & Cholera & {$[153,154]$} \\
\hline$>$ 4,500 (February 2014) & $\begin{array}{l}\text { Democratic } \\
\text { Republic of the } \\
\text { Congo }\end{array}$ & 2011-present & & Measles & {$[155,156]$} \\
\hline 170 & Vietnam & 2011-present & & $\begin{array}{l}\text { Hand, foot and } \\
\text { mouth disease }\end{array}$ & {$[157,158]$} \\
\hline$>350$ & Pakistan & 2011 & $\begin{array}{l}2011 \text { dengue outbreak } \\
\text { in Pakistan }\end{array}$ & Dengue fever & [159] \\
\hline $\begin{array}{c}171 \text { (as of } \\
10 \text { January 2013[update]) }\end{array}$ & Darfur Sudan & 2012 & $\begin{array}{c}2012 \text { yellow fever } \\
\text { outbreak in Darfur, } \\
\text { Sudan } \\
\end{array}$ & Yellow fever & {$[160]$} \\
\hline $\begin{array}{c}862 \text { (as of } \\
13 \text { January 2020[update]) }\end{array}$ & Worldwide & 2012-present & $\begin{array}{l}2012 \text { Middle East } \\
\text { respiratory syndrome } \\
\text { coronavirus outbreak }\end{array}$ & $\begin{array}{l}\text { Middle East } \\
\text { respiratory } \\
\text { syndrome }\end{array}$ & {$[161-163]$} \\
\hline 142 & Vietnam & $2013-2014$ & & Measles & {$[164]$} \\
\hline$>>11,300$ & $\begin{array}{c}\text { Worldwide, } \\
\text { primarily } \\
\text { concentrated in } \\
\text { West Africa } \\
\end{array}$ & $2013-2016$ & $\begin{array}{l}\text { Ebola virus epidemic } \\
\text { in West Africa }\end{array}$ & $\begin{array}{l}\text { Ebola virus } \\
\text { disease Ebola } \\
\text { virus virion }\end{array}$ & {$[165-167]$} \\
\hline 183 & Americas & $2013-2015$ & $\begin{array}{c}\text { 2013-14 Chikungunya } \\
\text { outbreak }\end{array}$ & Chikungunya & {$[168]$} \\
\hline 40 & Madagascar & $2014-2017$ & $\begin{array}{c}2014 \text { Madagascar } \\
\text { plague outbreak }\end{array}$ & Bubonic plague & [169] \\
\hline 36 & India & 2014-2015 & $\begin{array}{l}2014 \text { Odisha jaundice } \\
\text { outbreak }\end{array}$ & $\begin{array}{c}\text { Primarily } \\
\text { Hepatitis E, but } \\
\text { also Hepatitis A }\end{array}$ & {$[170]$} \\
\hline
\end{tabular}




\begin{tabular}{|c|c|c|c|c|c|}
\hline 2,035 & India & 2015 & $\begin{array}{l}2015 \text { Indian swine flu } \\
\text { outbreak }\end{array}$ & $\begin{array}{l}\text { Influenza A virus } \\
\text { subtype H1N1 }\end{array}$ & {$[170-173]$} \\
\hline$\sim 53$ & Worldwide & $2015-2016$ & $\begin{array}{l}\text { 2015-16 Zika virus } \\
\text { epidemic }\end{array}$ & Zika virus & {$[174]$} \\
\hline $\begin{array}{c}100 \text { 's (as of } \\
1 \text { April 2016[update]) }\end{array}$ & Africa & 2016 & $\begin{array}{l}2016 \text { yellow fever } \\
\text { outbreak in Angola }\end{array}$ & Yellow fever & {$[175]$} \\
\hline $\begin{array}{c}3,886 \text { (as of } \\
30 \text { November 2019[update]) }\end{array}$ & Yemen & 2016-present & $\begin{array}{l}\text { 2016-17 Yemen } \\
\text { cholera outbreak }\end{array}$ & Cholera & {$[176]$} \\
\hline $\begin{array}{l}64 \text { (as of } \\
16 \text { August 2017[update]) }\end{array}$ & India & 2017 & $\begin{array}{c}2017 \text { Gorakhpur } \\
\text { Japanese encephalitis } \\
\text { outbreak }\end{array}$ & $\begin{array}{l}\text { Japanese } \\
\text { encephalitis }\end{array}$ & {$[177]$} \\
\hline $\begin{array}{c}18 \text { (as of } \\
\text { February } 2020 \text { [update]) }\end{array}$ & India & 2018 & $\begin{array}{l}2018 \text { Nipah virus } \\
\text { outbreak in Kerala }\end{array}$ & $\begin{array}{l}\text { Nipah virus } \\
\text { infection }\end{array}$ & [178] \\
\hline $\begin{array}{c}2,253 \text { (as of } \\
20 \text { February 2020[update]) }\end{array}$ & $\begin{array}{c}\text { Democratic } \\
\text { Republic of the } \\
\text { Congo \& Uganda }\end{array}$ & $\begin{array}{c}\text { August } \\
\text { 2018-present }\end{array}$ & $\begin{array}{l}\text { 2018-19 Kivu Ebola } \\
\text { epidemic }\end{array}$ & $\begin{array}{l}\text { Ebola virus } \\
\text { disease }\end{array}$ & {$[179,180]$} \\
\hline$>6,000$ (by January 2019) & $\begin{array}{c}\text { Democratic } \\
\text { Republic of the } \\
\text { Congo }\end{array}$ & 2019-present & $\begin{array}{c}2019 \text { measles } \\
\text { outbreak in the } \\
\text { Democratic Republic } \\
\text { of the Congo }\end{array}$ & Measles & [181] \\
\hline 83 & Samoa & 2019-present & $\begin{array}{l}2019 \text { Samoa measles } \\
\text { outbreak }\end{array}$ & Measles & {$[182]$} \\
\hline $\begin{array}{c}3,360 \text { (as of } \\
6 \text { March } 2020 \text { [update]) }\end{array}$ & Worldwide & 2019-present & $\begin{array}{c}\text { 2019-20 coronavirus } \\
\text { outbreak }\end{array}$ & COVID-19 & {$[183,184]$} \\
\hline
\end{tabular}

Table 6: $21^{\text {st }}$ century.

Coronaviruses are a group of viruses that cause diseases in mammals and birds. In humans, coronaviruses cause respiratory tract infections that are typically mild, such as some cases of the common cold (among other possible causes, predominantly rhinoviruses), though rarer forms can be lethal, such as SARS, MERS, and COVID-19. Symptoms vary in other species: in chickens, they cause an upper respiratory tract disease, while in cows and pigs they cause diarrhea. Coronaviruses constitute the subfamily Orthocoronavirinae, in the family Coronaviridae, order Nidovirales, and realm Ribavirin [185,186]. They are enveloped viruses with a positive-sense single-stranded RNA genome and a nucleocapsid of helical symmetry. The genome size of coronaviruses ranges from approximately 27 to 34kilobases, the largest among known RNA viruses [187].

\section{Evolution}

The most recent common ancestor (MRCA) of all coronaviruses has been placed at around 8000BCE [188]. The MRCAs of the Alpha-coronavirus line has been placed at about 2400BCE, the Beta-coronavirus line at 3300BCE, the Gamma-coronavirus line at 2800BCE, and the Deltacoronavirus line at about 3000BCE. It appears that bats and birds, as warm-blooded flying vertebrates, are ideal hosts for the coronavirus gene source (with bats for Alphacoronavirus and Beta coronavirus, and birds for Gammacoronavirus and Delta-coronavirus) to fuel coronavirus evolution and dissemination [189]. Bovine coronavirus and canine respiratory coronaviruses diverged from a common ancestor in 195 [190]. Bovine coronavirus and human coronavirus OC43 diverged around the 1890s. Bovine coronavirus diverged from the equine coronavirus species at the end of the 18th century [191]. The MRCA of human coronavirus OC43 has been dated to the 1950s [192]. MERS$\mathrm{CoV}$, although related to several bat coronavirus species, appears to have diverged from these several centuries ago [193]. The human coronavirus NL63 and a bat coronavirus 
shared an MRCA 563-822 years ago [194]. The most closely related bat coronavirus and SARS-CoV diverged in 1986 [195]. A path of evolution of the SARS virus and keen relationship with bats has been proposed. The coronaviruses have been coevolved with bats for a long time and the ancestors of SARS-CoV first infected the species of the genus Hipposideridae, subsequently spread to species of the Rhinolophidae and then to civets, and finally to humans [196,197]. Alpaca coronavirus and human coronavirus 229E diverged before 1960 [198].

\section{Discussion}

By mentioning all the facts, evolution and all the similarities from the viruses, we observe that all kinds of Flu including COVID-19 which have been caused many deaths through epidemic and pandemic of these giant but very small objects, all the viruses from the first one before the rise of the human in evolution, had been existed. Through my deep research, the first virus was or blue-green algae, predate viruses and are one of the oldest forms of life on Earth (Figure 4).

The researchers developed algorithms to compare the protein shapes of 3,460 viruses and 1,620 cells. They found that 442 protein folds were shared between cells and viruses, but 66 folds were unique to viruses. To make sense of the data, the team arranged the protein folds into a tree that grew a new 'branch' every time a new type of protein fold evolved. Wherever possible, the team used fossil evidence to put an approximate date on the budding of specific branches. For example, one particular protein fold was first seen in cyanobacteria (blue-green algae), and later appeared in all its descendants. By comparing when cyanobacteria first appeared in the fossil record (2.1billion years ago) to when its offspring later emerged, they could establish this particular fold appeared around 2 billion years ago. According to Caetano-Anolles's microbial family tree, viruses are ancient, however; they were not the first form of life. In fact, his family tree suggests viruses and bacteria share a common ancestor-a fully functioning, self-replicating cell that lived around 3.4billion years ago, shortly after life first emerged on the planet. From this cell, bacteria have evolved in the direction of increasing complexity, while viruses have gradually shed genes they found they didn't need, until they could no longer even reproduce on their own. A key step in the virus evolutionary journey seems to have come about around 1.5billion years ago and that's the age at which the 66 virus-specific protein folds came on the scene. These changes are to proteins in the virus' outer coat-the machinery viruses use to break into host cells. For Charleston, the remarkable point about the study is how many proteins today do bacteria and viruses have in common (Figure 5).

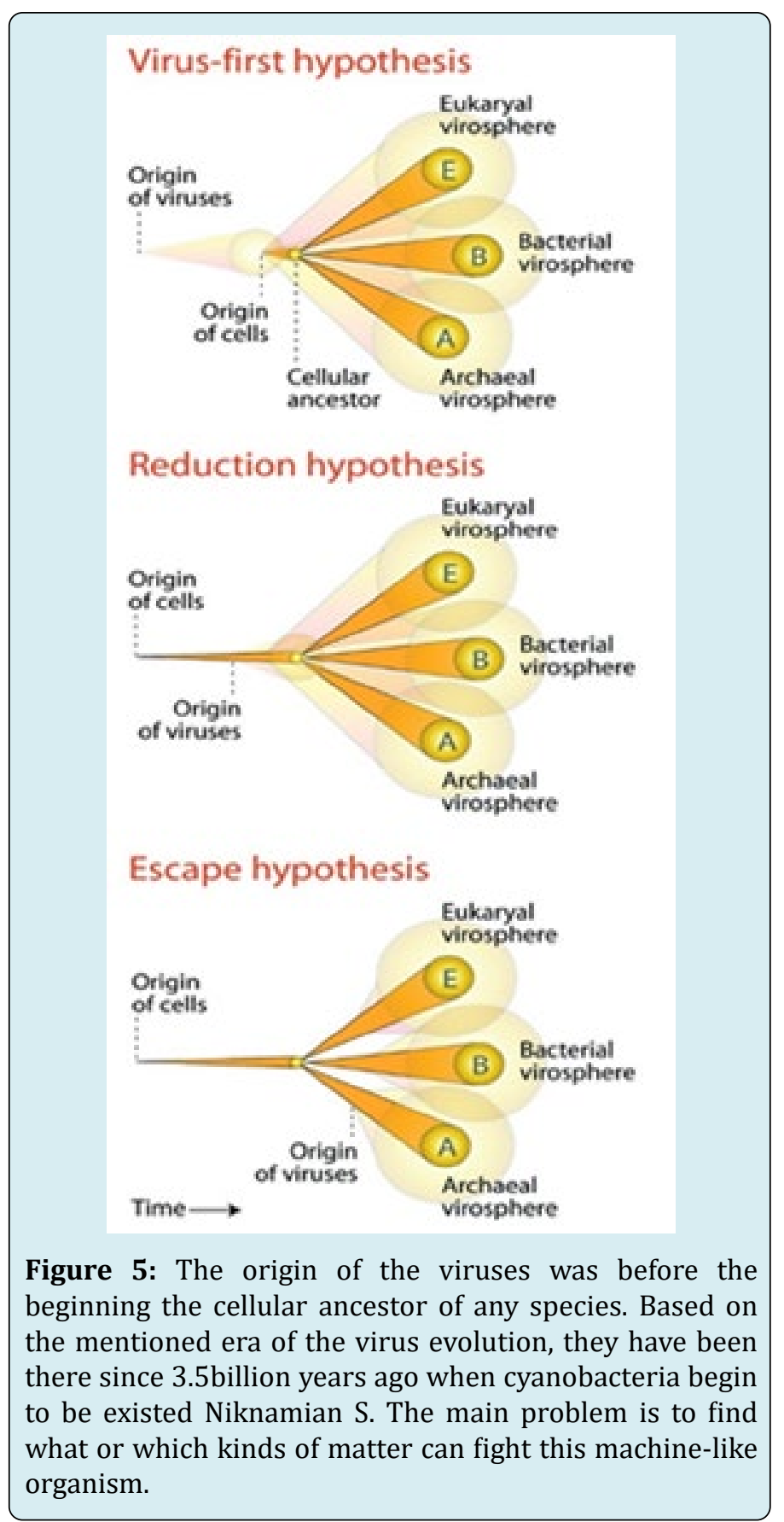

\section{Drift}

New viruses can also emerge by drift. Drift can refer to genetic drift or antigenic drift [199]. Mutation and selection for the most advantageous variation of the virus takes place during this form of evolution. Natural Selection and Lamarckian Evolution both caused the evolution of several viruses like Coronaviruses fast enough [199]. Antigenic mutants can evolve quickly due to the high mutation rate in 
viruses. The cause of the antigenic drift lies in the mechanisms of RNA synthesis itself. Mutations arise very easily simply due to the error prone RNA polymerase and its lack of proofreading mechanisms. These mutations lead to subtle changes in the HA and NA genes which completely changes the infectious capabilities of the virus. These changes allow for almost endless possibilities for new viral strains to arise [200] and it is the antigenic drift of the HA and NA genes that allow for the virus to infect humans that receive vaccines for other strains of the virus [201]. This evolution occurs under the pressure of antibodies or immune system responses. Seven strains of human coronaviruses are known and four of them produce the generally mild symptoms of the common cold:

a) Human coronavirus OC43 (HCoV-OC43).

b) Human coronavirus HKU1.

c) Human coronavirus NL63 (HCoV-NL63, New Haven coronavirus).

d) Human coronavirus 229E (HCoV-229E) and three coronaviruses that are potentially fatal.

e) Middle East respiratory syndrome-related coronavirus (MERS-CoV), previously known as novel coronavirus 2012 and HCoV-EMC.

f) Severe acute respiratory syndrome coronavirus (SARSCoV or "SARS-classic").

g) Severe acute respiratory syndrome coronavirus 2 (SARSCoV-2), previously known as 2019-nCoV or "novel coronavirus 2019" [202] (Figure 6).

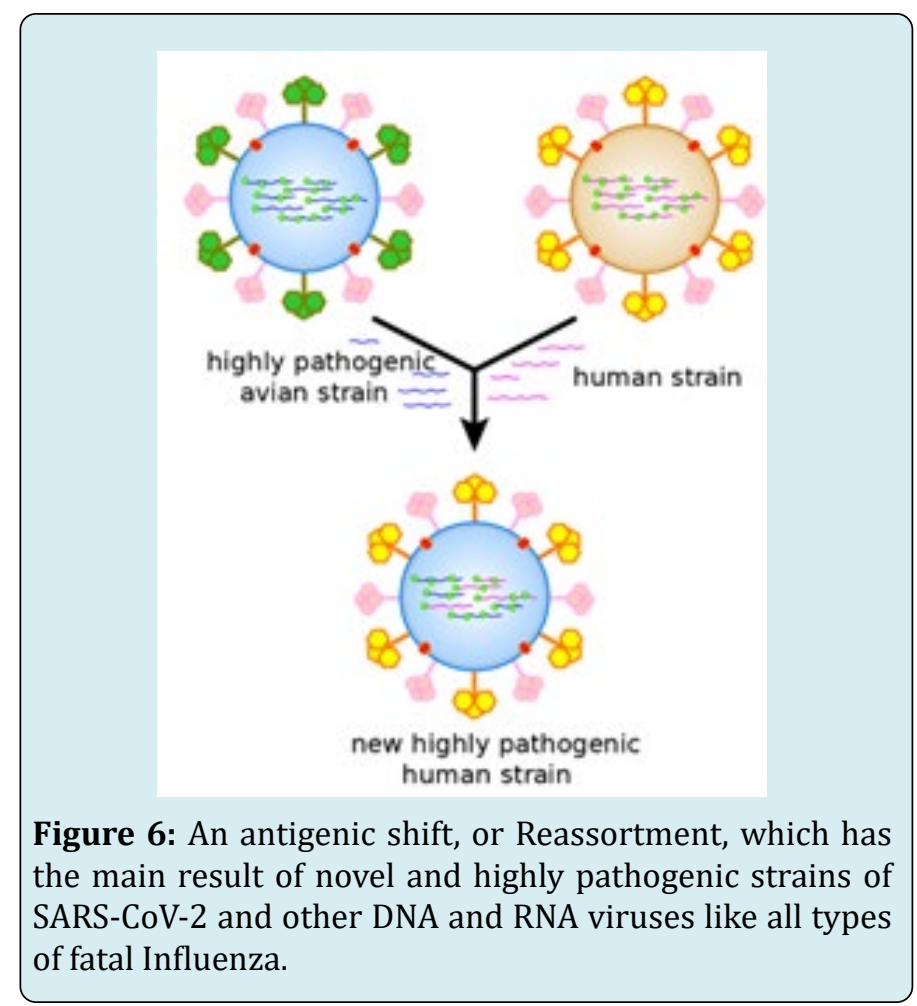

\section{Reassortment}

Reassortment, also known as antigenic shift, allows new viruses to evolve under both natural conditions and in artificial cultures [199]. Reassortment occurs in a similar way as chromosome crossover events, as two different viral strains may come in contact and transfer some of their genetic information. This crossing-over event creates a mixture of the two viral strains, which may replicate as one hybrid virus that expresses traits from both original viruses [203]. The mechanism of the evolutionary force of antigenic shift allows influenza viruses to exchange genes with strains that infect different species. Under this mechanism, a human influenza virus could exchange genes with an avian strain, and that is how pandemic strains arise. There have been three occurrences of pandemics caused by antigenic shift since 1900, and it has happened again today as we know as SARS-CoV-2 [204]. In fact, the 1957 evolution of the H2N2 virus is thought to be a result of Reassortment [205]. In this case, human H1N1 strains and avian influenza genes were mixed [206]. Infecting tissue cultures can demonstrate how pathogenic qualities can evolve for a particular species even though the reasserted virus may be nonpathogenic for another species [207]. A prime example of evolution under natural conditions is the Reassortment of two avian influenza strains that were discovered in dead seals back in 1979 [208].

Based on research by Fairchild GA, Inhalation of ozone and sulfur dioxide inhibited influenza virus growth in the nose of mice. Ozone inhalation caused the more pronounced inhibition of influenza virus growth: $0.6 \mathrm{ppm}$ ozone for 3 hours' post-virus exposure almost completely inhibited influenza virus growth in the nose, whereas sulfur dioxide $6 \mathrm{ppm}$ for 7 days) causes only partial inhibition of influenza growth in the nose. Neither gas altered the propagation of influenza virus in the lungs of mice. Vesicular stomatitis virus (VSV) growth was either unaffected by exposure to ozone $(0.9 \mathrm{ppm}$ for 3hours) or, when ozone exposure preceded VSV exposure, the virus may have grown to slightly higher titer [209]. The inhibitory effect of ozone and sulfur dioxide on influenza virus growth in nasal epithelium suggests a competitive interaction between the chemical inhalant, the virus, and host tissues, with net consequences for the pathogenesis of this disease [210]. If the effects of these inhalants are to be properly interpreted, they should be determined for all major regions of virus growth and inhalant deposition. Therefore; inhalation of Ozone plus Sulfur Dioxide may inhibit the influenza virus growth in humans as well.

Another research in 1947 by Rose HM, indicated that Influenza virus was rendered noninfectious for mice by in 
vitro exposure to relatively high concentrations of sulfur and nitrogen mustards. Concentrations of the mustards that abolished infectivity did not reduce the ability of the virus to agglutinate erythrocytes [211]. The parenteral administration of nitrogen mustard had no effect on the course of infection with influenza virus in mice.

There are several researches on the compound L-Glutathione which contains high sulfur amounts and it is normally produced by liver but the amounts vary in ages and sexes in its compound and inhibit viral infection. Lima JE, Palamara AT, Ghezzi P, Jing An, Aukrust P, Palamara AT, Fraternale A, Forman HJ, Aquilano K, Reshi ML. These researches has done in in Vivo and in Vitro with controlled groups double blind and received totally positive results and the treatment of the patients with several most dangerous viral diseases including Coronaviruses.

\section{Sulfur and Viruses}

Scientists have known about viruses that attack bacteria since the early twentieth century. In 1917, Felix d'Herelle, a French-Canadian microbiologist, and his colleagues successfully isolated phages that kill bacteria like E. coli, salmonella, and dysentery, and doctors used his so-called phage therapies to treat disease. But phage research lost steam in the 1950s in the face of penicillin and other powerful new antibiotics. Bacteria are living micro-organism which can be affected by viruses [211]. The adaptation of bacteria to fight viruses is higher than human living cells. Therefore; this is the most important research on Phages against viruses which should be considered by scientists to fight against all viruses including 2019-Coronavirus. Paula Dalcin Martins and his colleagues reached positive results using Sulfur against many viruses, Martins PD. Basically If two viruses share a good number of genes [212]; they are probably related like MERS, SARS and 2019-Coronavirus. The fewer genes they share, the more divergent their evolutionary paths [213]. The most impressive article about sulfur against viruses has been published by Matthew B Sullivan which indicated Sulfur can kill and terminate any known viruses in eukaryotic host cells, Sullivan MB. Based on Felix d'Herelle and Matthew B Sullivan statements and articles, Sulfur and Phage Therapies can be one of the main treatment of viral diseases through coevolution hypothesis (coevolution occurs when two or more species reciprocally affect each other's evolution through the process of natural selection like viruses and mammals.) including SARS-CoV-2 (Figures 7-10).

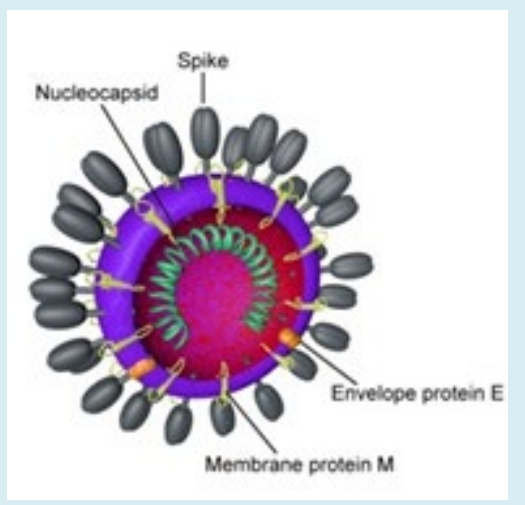

Figure 7: Diagram of coronavirus Virion structure.

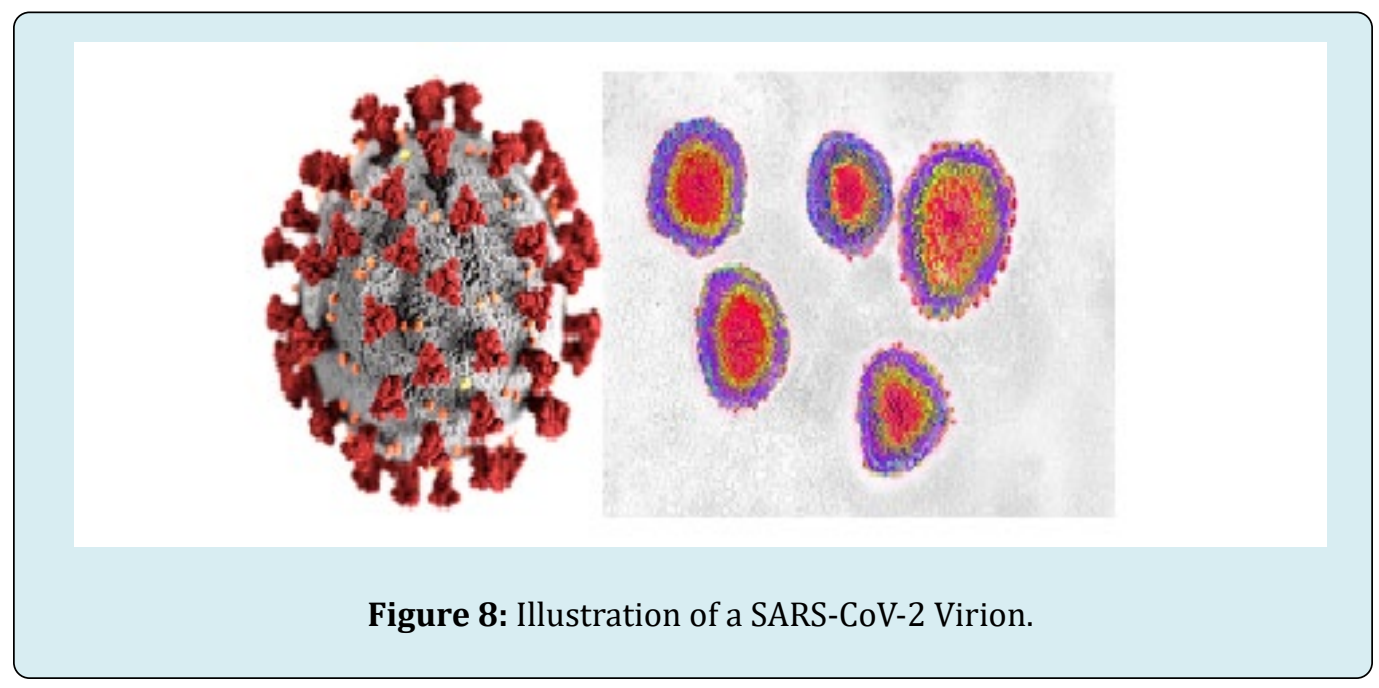




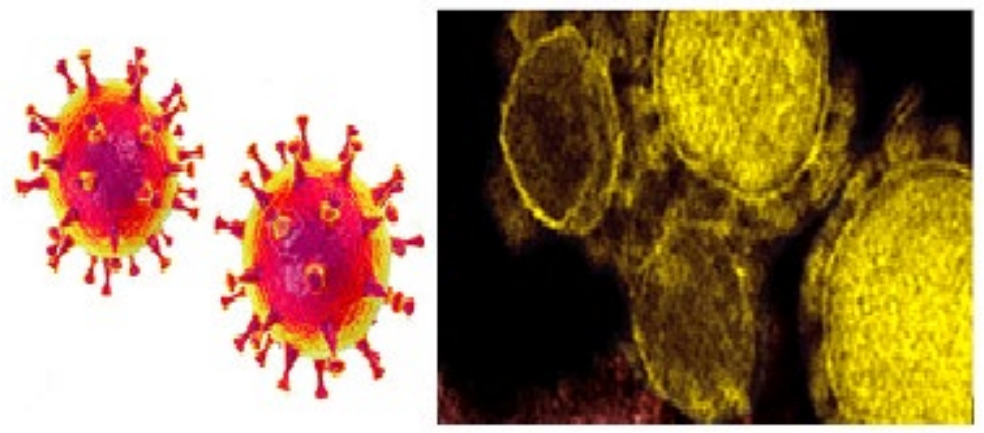

Figure 9: MERS virus, Middle-East Respiratory Syndrome coronavirus Virion, (Camel Flu) [214].

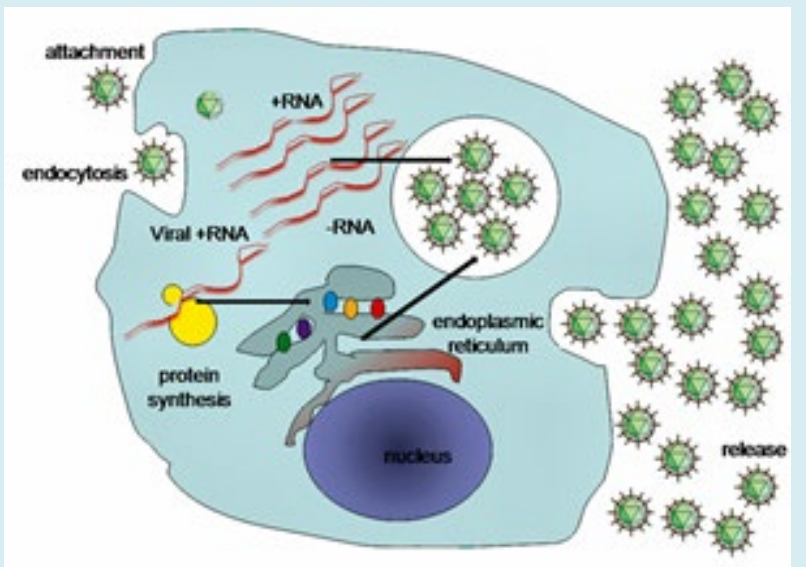

Figure 10: A typical virus replication cycle including Sars-Cov-2019. 2019-nCoV is sufficiently divergent from SARS-CoV to be considered a new human-infecting beta coronavirus.

Although our phylogenetic analysis suggests that bats might be the original host of this virus, an animal sold at the seafood market in Wuhan might represent an intermediate host facilitating the emergence of the virus in humans. Importantly [215-218], structural analysis suggests that $2019-\mathrm{nCoV}$ might be able to bind to the angiotensinconverting enzyme 2 receptor in humans. The future evolution, adaptation, and spread of this virus warrant urgent investigation.

In Taxonomy, the family Coronaviridae is organized in 2 sub-families, 5 genera, 23sub-genera and about 40species-Coronaviridae-Orthocoronavirinae-LetovirinaeAlphaletovirus-Milecovirus and then Microhyla letovirus [23].
MERS-CoV and Severe acute respiratory syndrome (SARS) are beta coronavirus derived from bats [219,220]. Between November 2002 and July 2003, an outbreak of SARS in southern China caused an eventual 8,098 cases, resulting in 774 deaths reported in 17 countries (9.6\% fatality rate), with the majority of cases in mainland China and Hong Kong. No cases of SARS have been reported worldwide since 2004. In late 2017 [221-224], Chinese scientists traced the virus through the intermediary of civets to cave-dwelling horseshoe bats in Yunnan province [225-228]. Therefore; through the lines above, SARS and COVID-19 outbreak was first observed in China. The coronaviruses HCoV-229E, -NL63, -OC43, and -HKU1 continually circulate in the human population and cause respiratory infections in adults and children world-wide [229].

In the new Coronavirus, Genetic recombination which is the process by a strand of DNA that is broken and then joined to the end of a different DNA molecule. This can occur when viruses infect cells simultaneously and studies of viral evolution have shown that recombination has been rampant in the species studied [230]. Recombination is common to both RNA and DNA viruses [108,231]. SARS-CoV-2 has undergone genetic change by several mechanisms. These include an antigenic drift process where individual bases in the RNA mutate to other bases. The mutation of this virus is silent means it does not change the protein that the gene encodes and confers evolutionary advantages such as resistance to antiviral drugs [230-234]. Therefore; we cannot mention there would be any possible antiviral drugs to resist this kind of virus even in the future.

SARS-CoV-2 is an RNA virus its nucleic acid is singlestranded RNA (ssRNA). The polarity of this virus is positivesense $((+)$ ssRNA). Positive-sense viral RNA is similar to mRNA and thus can be immediately translated by the 
host cell. Recombination in RNA viruses appears to be an adaptation for coping with genome damage. Recombination can occur infrequently between animal viruses of the same species but of divergent lineages. The resulting recombinant viruses may sometimes cause an outbreak of infection in humans. RNA viruses have very high mutation rates. This is one reason why it is difficult to make effective vaccines to prevent diseases caused by RNA viruses [235,236].

\section{Mathematical Calculation of SARS-CoV-2 and Future Concerns}

The Factorial formula is:

Factorial formula by Product

$$
n !=\prod_{k=1}^{n} k
$$

Factorial Formula by Recurrence Relation

$$
n !=\left\{\begin{array}{ll}
1 & \text { if } n=0 \\
(n-1) ! * n & \text { if } n>0
\end{array}\right\}
$$

The size of SARS-CoV-2 is approximately 0.3 microns [237]. With conversion of Micrometer into nanometer, 0.3 will be $300 \mathrm{~nm}$ in size. In page 21 , we have described the Antigenic Drift of viruses especially SARS-CoV-2. The mathematical calculation of how many types of this virus exist is: $3 \times 4$, since we have 4 types of mild coronavirus and 3 types of deadly with severe symptoms. So the numbers of different coronaviruses will be $3 \times 4=12$. Therefore; based on each type of virus is different from another one, we use Factorial to measure all types of coronavirus which exists on earth till now without the concern of the mutation in vivo of the virus. It is $12 !=479001600$. Overall, the number of different SARS-CoV-2 is about 479001600 . Each of these kinds of viruses when get inside their hosts also mutates Therefore; Each of these coronaviruses get inside their host will have different symptoms from mild into severe based on the host's immune system response and other factors. Hence; all these SARS-CoV-2, will mutate and possible severe symptoms will occur based on the Reassortment of the virus which have been described in page 22 . The probability of each person in the world who may contaminate with this virus is 7.8 Billion/479001600 equals 16.2838704505 . This is the probability from the first time outbreak of the virus means approximately $16 \%$ of the population infected by the virus. So the near future of death or infected people from SARSCoV-2 will be 1248000000 . Based on high rates of mutation of 2019-Corovirus, each carrier of this deadly virus may/will contaminate another living human. Therefore; all people will carry this virus in the near future. We do not know the time range of this highly pandemic, but the lesson that we have learnt from the history is that the only way to fight the virus will not produce new vaccines, since the adaptation and the mutation of the virus is higher than any known ones on earth. The only answer to end the pandemic is the adaptation of human race to SARS-CoV-2 through Lamarckian Evolution. This infectious disease with 7.8billion people living on earth is like playing with dices and the people contamination is random in mathematical Theorems. Some may adapt to the virus, some will die and the rest will be the carrier, therefore; the graph we predict is like the bean machine, a device invented by Francis Galton shown below (Figure 11):

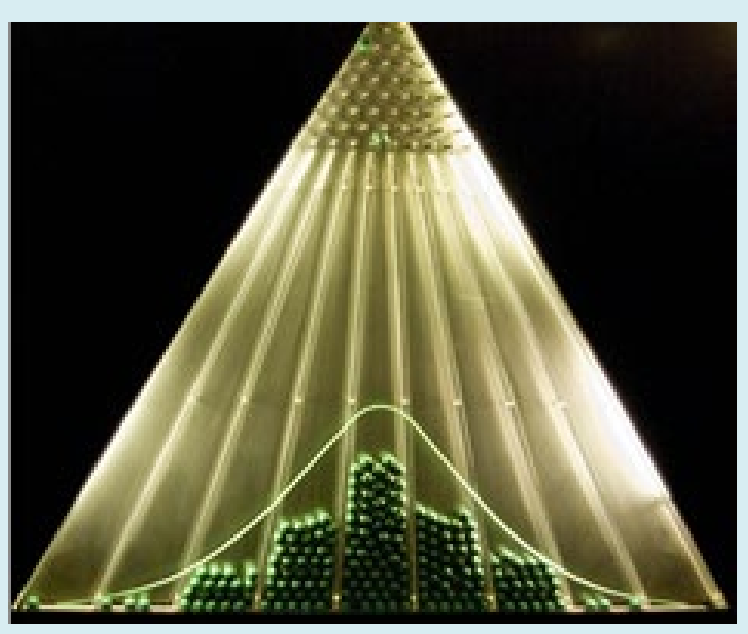

Figure 11: The bean machine, a device invented by Francis Galton, can be called the first generator of normal random variables. This machine consists of a vertical board with interleaved rows of pins. Small balls are dropped from the top and then bounce randomly left or right as they hit the pins. The balls are collected into bins at the bottom and settle down into a pattern resembling the Gaussian curve.

According to the central limit theorem (more specifically, the de Moivre-Laplace theorem), the binomial distribution approximates the normal distribution provided that the number of rows and the number of balls are both large. Varying the rows will result in different standard deviations or widths of the bell-shaped curve or the normal distribution in the bins $[238,239]$.

\section{9-Corovirus Relation to Fibonacci Sequence}

The Fibonacci numbers, commonly denoted Fn, is a function called the Fibonacci sequence, means each number is the sum of the two preceding numbers, starting from 0 and 1 :

$$
\begin{gathered}
F_{0}=0, \quad F_{1}=1, \\
F_{n}=F_{n-1}+F_{n-2},
\end{gathered}
$$


And the sequence is: $0,1,1,2,3,5,8,13,21,24,34,55,89$, $114 \ldots$

We have collected the infected people with COVID-19. If we suppose each infected individual infects one other individual each day and at the end of day-two recovers fully or dies (we are interested in the number of people who are actively infected and alive). So the time stamps are the beginning of day-one, at the end of day-one and at the end of day-two. According to our model, an infected individual can infect one other person at the end of day-one and at the end of day-two. If we go on through time (days), the table below shows the result of infected people (Figures 12-14):

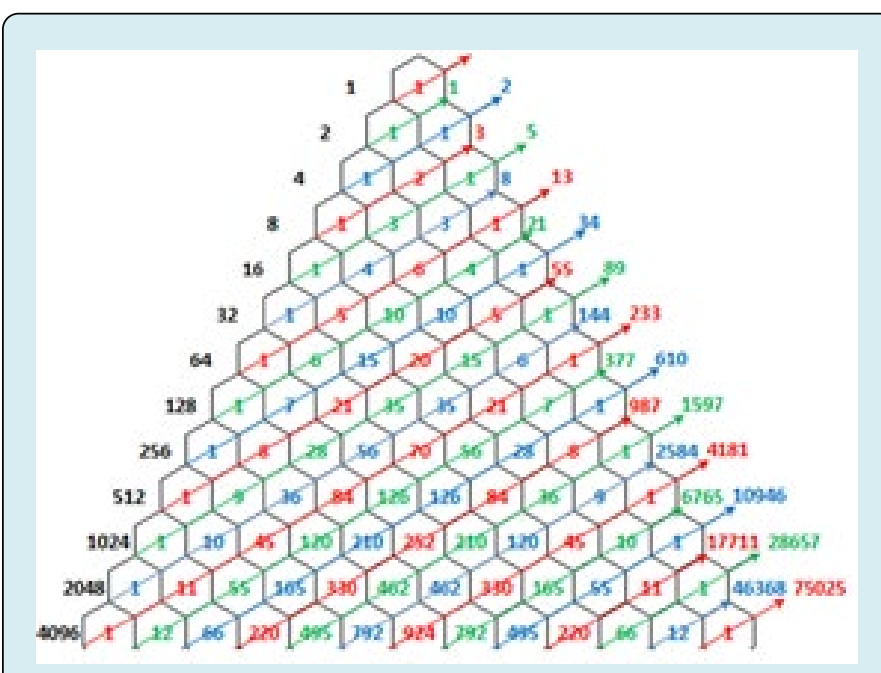

Figure 12: The right vertical numbers shows the infected people per day.

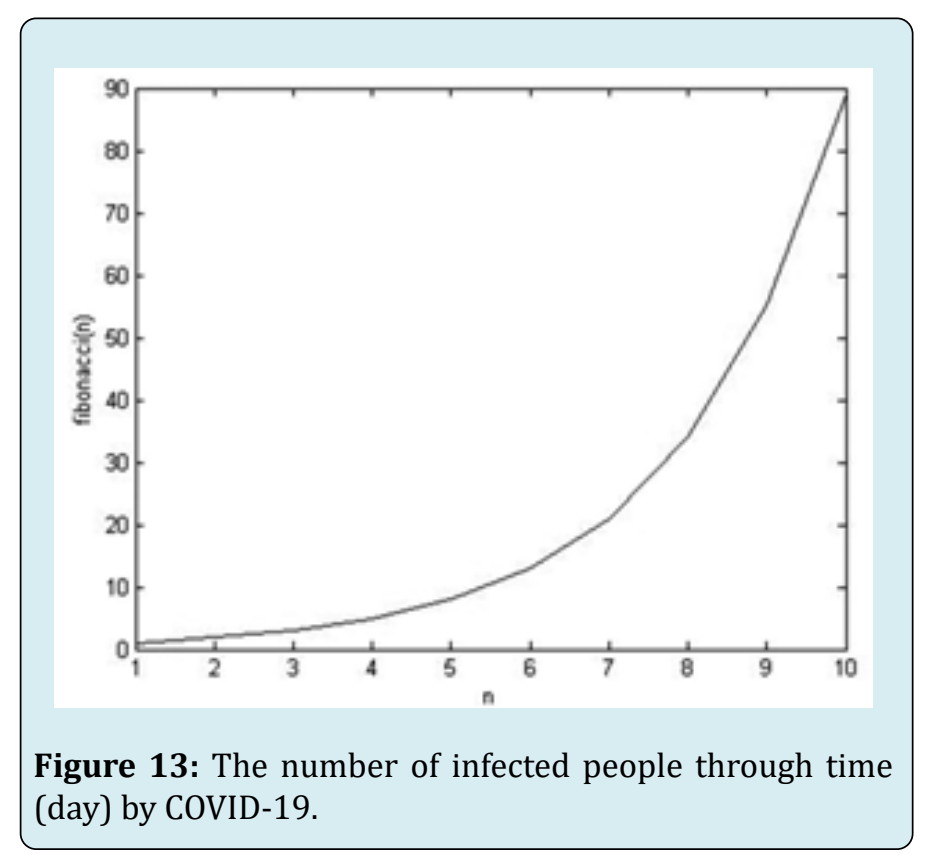

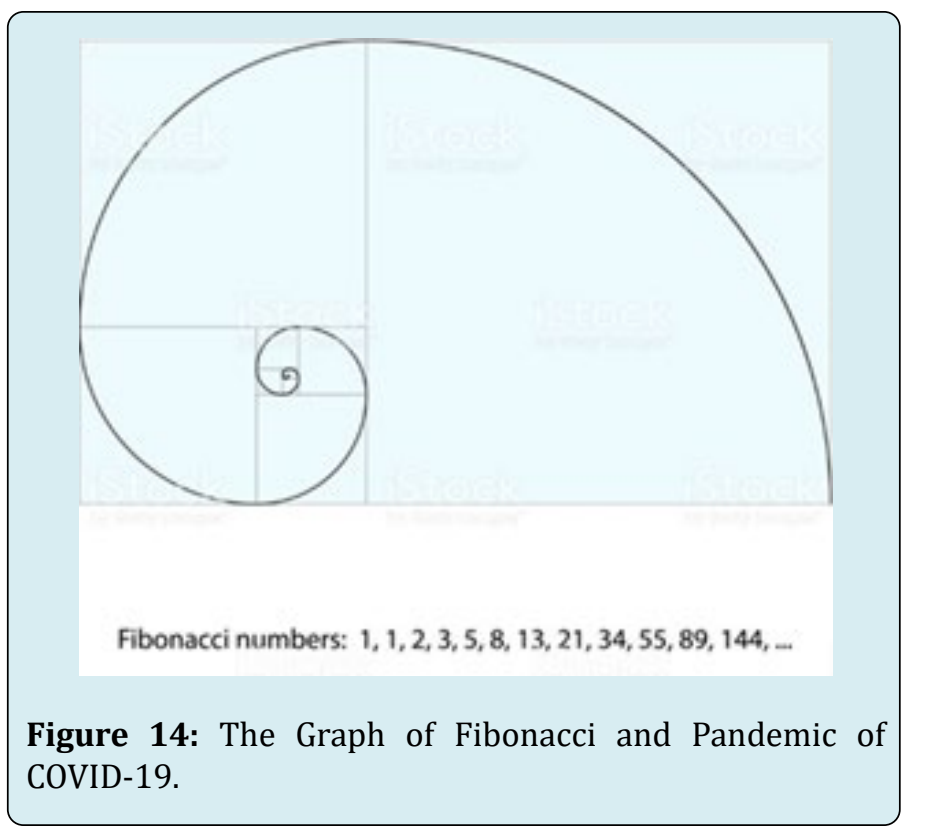

Therefore; the formula of infected people per day is: $F_{n}=F_{n-1}+F_{n-2}($ for $\mathrm{n}>2)$, which is the formula of Fibonacci series.

\section{Viruses Related to COVID-2019}

There are some viruses that cause respiratory infection. Enteroviruses, Poliovirus, coxsackie, echovirus and Human orthopneumovirus. Hence; none of them has been related to 2019-Coronavirus. Since their Signs and symptoms, Structure, Genome, Evolution, Taxonomy and Transmission are not similar to the new COVID-2019. The only virus that has been correlated with COVID-2019 is Rhinovirus. The rhinovirus is the most common viral infectious agent in humans and is the predominant cause of the common cold and flu. Rhinovirus infection proliferates in temperatures of $33-35^{\circ} \mathrm{C}\left(91-95^{\circ} \mathrm{F}\right)$, the temperatures found in the nose. The three species of rhinovirus (A, B, and C) include around 160 recognized types of human rhinovirus that differ according to their surface proteins (serotypes) They are lytic in nature and are among the smallest viruses, with diameters of about 30 nanometers. By comparison, other viruses, such as smallpox and vaccinia, are around ten times larger at about 300 nanometers (the same diameter as COVID-2019 which is 300nanometers in size) [240]. There are two modes of transmission: via aerosols of respiratory droplets and from fomites (contaminated surfaces), including direct personto-person contact. Rhinoviruses are spread worldwide and are the primary cause of the common cold. Symptoms include sore throat, runny nose, nasal congestion, sneezing and cough. Those most affected by rhinoviruses are infants, the elderly, and immune compromised people (Most elderly and Children). Human rhinoviruses preferentially grow at 


\section{Open Access Journal of Mycology \& Mycological Sciences}

$32^{\circ} \mathrm{C}\left(89^{\circ} \mathrm{F}\right)$, notably colder than the average human body temperature of $37^{\circ} \mathrm{C}\left(98^{\circ} \mathrm{F}\right)$; hence the virus s tendency to infect the upper respiratory tract, where respiratory airflow is in continual contact with the (colder) extra somatic environment [241]. Rhinoviruses have single-stranded positive sense RNA genomes of between 7200 and 8500nt in length. At the $5^{\prime}$ end of the genome is a virus-encoded protein, and like mammalian mRNA, there is a $3^{\prime}$ poly-A tail. Structural proteins are encoded in the $5^{\prime}$ region of the genome and nonstructural at the $3^{\prime}$ end. This is the same for all picornaviruses. The viral particles themselves are not enveloped and are icosahedral in structure. The viral proteins are translated as a single, long polypeptide, which is cleaved into the structural and nonstructural viral proteins [242]. Human rhinoviruses are composed of a capsid that contains four viral proteins, VP1, VP2, VP3 and VP4.VP1, VP2, and VP3 form the major part of the protein capsid. The much smaller VP4 protein has a more extended structure, and lies at the interface between the capsid and the RNA genome. There are 60copies of each of these proteins assembled as an icosahedron. Antibodies are a major defense against infection with the epitopes lying on the exterior regions of VP1-VP3. Human rhinovirus is most contagious during the autumn and winter months. The virus can remain activated for up to 3hours outside of a human host. Once the virus is contracted, a person is most contagious within the first 3 days. Preventive measures such as regular vigorous hand washing with soap and water may aid in avoiding infection. Avoiding touching the mouth, eyes and nose, the most common entry points for rhinovirus, may also aid in prevention. Droplet precautions, which take the form of a surgical mask and gloves, are the method used in major hospitals [243-245]. As mentioned, through our analysis, the most related virus to COVID-2019, is Rhinovirus which has very similar in Structure, Genome, Size and symptoms of the SARS-CoV-2. There has not been an effective anti-viral vaccination of this virus either. There is a high possibility of mutation in this virus into 2019-Coronavirus. In 2018, a new series of anti-rhino viral compounds were reported by researchers at Imperial College London and colleagues at the University of York and the Pirbright Institute. These molecules target human $\mathrm{N}$-myristoyltransferase, an enzyme in the host cell which picornaviruses require in order to assemble its viral capsid, and thus generate an infectious virion. The lead compound in this series, IMP-1088, very potently inhibited host myristoylation of viral capsid protein and prevented infectious virus formation, rescuing the viability of cells in culture which had been exposed to a variety of rhinovirus serotypes, or to related picornaviruses including poliovirus and foot-and-mouth-disease virus. Because these compounds target a host factor, they are broadly active against all serotypes, and it is thought to be unlikely that they can be overcome by resistance mutations in the virus [246-248].

\section{The Main Cause of COVID-19 Pandemic}

Through the lines and statements in this article, we hypothesize that the prime cause of SARS-CoV-2 is:

$>$ The coevolution and Red Queen effect between mammals including humans and viruses. Coevolution occurs when two or more species reciprocally affect each other's evolution through the process of natural selection and the Red Queen effect which is an evolutionary hypothesis that proposes organisms must constantly adapt, evolve, and proliferate in order to survive while pitted against ever-evolving opposing organisms in a constantly changing environment, as well as to gain reproductive advantage. Increasing human population, antibiotic resistance, antiviral resistance, malnutrition, immune deficiency (basically nutrition low in sulfur), low adaptation of human in their environment (Lamarckian Evolution) and high adaptation of viruses with human genome [249-250].

$>$ The main cause of SARS-CoV-2 is through natural selection and Lamarckian Evolution Both which caused this RNA virus so powerful and different in the nations worldwide. The first Pandemic of Influenza was detected in 1732 and this virus evolved through natural selection till 2019 through Drift and Reassortment of SARS-CoV-1 and Influenza viruses which caused the worldwide pandemic of SARS-CoV-2. There may be a correlation between Rhinoviruses and COVID-19 which has not been studied yet and should be considered $[45,46,240]$.

\section{The Possible Treatment of COVID-19 (SARS- CoV-2)}

Based on our research/Review of many major researches, there have not been any antiviral vaccines against these viruses and no antiviral drugs will be useful against COVID-19 since the adaptation and high mutation of this virus will not let these drugs be effective. The prime possible treatment Inhalation of ozone and sulfur dioxide, increasing L-Glutathione plus Viral Phage Therapy (VFT) is the possible prime treatment of this disease. Finding the right Phage Therapy is very hard in any viral infections since this therapy was mainly used against bacterial infections. However; through our research and findings we have concluded that substantial dose-dependent inhibition by T4phage of adsorption of HAdV to both A549 and HEK293 cell lines in vitro LPS was without effect. Moreover, T4phage protected A549 cells from a HAdV-induced cytopathic effect. These data suggest that T4phage could be considered as a potential novel antiviral agent. The capacity of the phage to inhibit HAdV infection at the stage of viral replication suggests that phage could also interfere with viruses using cellular receptors other than those used by HAdV. Notably, 


\section{Open Access Journal of Mycology \& Mycological Sciences}

the anti-viral effect of phage was measured as the decrease of the end-point HAdV infectious titer. Further in vitro studies were carried out on the effects of T4 and the staphylococcal phage A5/80 on HAdV DNA synthesis (real-time PCR) and the expression of its early and late genes (measured at the level of mRNA synthesis) in an A549 cell culture. Continuous incubation of adenovirus-infected cells with T4 phage significantly reduced the level of adenoviral DNA synthesis (this effect was not observed with the staphylococcal phage). Coincubation with a high titer of T4 phage was required for inhibition of HAdV early gene expression. Late adenoviral gene expression was reduced by preincubation (application of phage prior to HAdV infection) and Coincubation with both phages when a low HAdV titer was used. In contrast, when a high HAdV titer was applied, both incubation and preincubation with T4phage were inhibitory whilst a staphylococcal phage was inhibitory only when continuous incubation with cells was applied. Those results suggest that the inhibitory effect of phage on HAdV infection may differ and may be partially explained by their influence on the expression of early and late adenoviral genes. When the effect of both phages on the expression of genes involved in antimicrobial immunity by the A549 cell line from human lung was studied, the most striking phenomenon was marked ( $>10$-fold) enhancement of a gene coding for interleukin-2 (Il-2) by a staphylococcal phage. This effect is of particular interest in the context of the well-known role of NK cells in the immune response to viruses and the ability of Il-2 to induce those cells -even in ultra-low doses. Interestingly, a resident NK cell population is present in the human lung and may provide early and important control of viral infection. Moreover, NK cells also exhibit activity against a variety of bacteria, e.g., by secretion of the soluble molecules perforin and granulysin. Mice infected with Shigella and lacking B and T cells but with normal NK cells have higher survival rates and lower bacterial titers than mice which lack all three cell types. This suggests that phage-induced Il-2 dependent activation of NK-mediated antimicrobial activity may contribute to beneficial effects of PT; especially during prolonged phage administration cumulative median duration of successful phage therapy is 43 days. NK cells could be a promising agent in antimicrobial immunotherapy, as data strongly suggest that these cells are active against not only viral but also bacterial and fungal pathogens.

\section{Conclusion}

In this Research/Review articles, we have gone through all the cases and epidemic of all the fatal diseases from the first time mentioned in history including Flu/Influenza pandemic until 2020. Based on our research, the only period of time when there was no outbreak of influenza, RNA viruses or infectious diseases were during World War 2, where German scientists controlled the epidemic of any virus infections which should be noted by the scientists and researchers. The mutation of the SARS-CoV and Influenza viruses is the main cause of SARS-CoV-2 through natural selection and Lamarckian Evolution Both which caused this RNA virus so powerful and different in the nations worldwide. The first Pandemic of Influenza was first detected in 1732 and this virus evolved through natural selection till 2019 which caused the worldwide pandemic of SARS-CoV-2. Based on many studies, inhalation of Ozone plus Sulfur Dioxide, increasing the amounts of L-Glutathione (Which is low in children and older adults) plus Viral Phage Therapy (VPT) can be the prime treatment of SARS-CoV-2 infection. The seasonal temperature cannot be useful in controlling or reducing the pandemic of this virus since the temperature rises gradually and the natural selection, Lamarckian Evolution and high mutation rate of the virus helps its survival. In our mathematical calculation, the number of infected people is/will be 1248000000 which should not be ignored by the scientists. We also introduced the Fibonacci Model in calculating the infected/will be infected people. Through our research we have found that no antiviral drugs will be useful against SARS-CoV-2 because of high rate of mutation and adaptation of the virus to the drugs and even the environment temperature.

\section{Acknowledgement}

We would like to thank Senator Mark R Warner, Senator Tim Kaine and Representative Ben Cline for their inspirational help and dedication their time and help to the United States of America. Also, we would like to thank Mrs. Fallon Morell the President of Weston A Price Foundation (WAPF), Professor Stephanie Seneff (senior research scientist at the Computer Science and Artificial Intelligence Laboratory (CSAIL), Massachusetts Institute of Technology), Professor Thomas N Seyfried (Morrissey College of Arts and Sciences) and Professor Dominic D’Agostino (Research Scientist, Inst. Human and Machine Cognition, Professor, College of Medicine Molecular Pharmacology \& Physiology, Morsani College of Medicine, Molecular Pharmacology \& Physiology for their motivational help in my beginning of our first research till now.

\section{References}

1. McMichael AJ (2004) Environmental and social influences on emerging infectious diseases: past, present and future. Philos Trans R Soc Lond B Biol Sci 359(1447): 1049-1058.

2. Lewis and Clarke's Expedition, pp: 56.

3. Barrett and Armelagos, pp: 28.

4. Luis P. Villarreal-Publications, pp: 344. 
5. Hughes AL, Irausquin S, Friedman R (2010) The evolutionary biology of poxviruses. Infect Genet Evol 10(1): 50-59.

6. Georges AJ, Matton T, Georges MC (2004) Monkey-pox, a model of emergent then reemergent disease. Med Mal Infect 34(1): 12-19.

7. Tucker Netherton, University of Texas. USA.

8. Clark, pp: 20.

9. Barker Code.

10. Gibbs AJ, Ohshima K, Phillips MJ, Gibbs MJ (2008) The prehistory of potyviruses: their initial radiation was during the dawn of agriculture. PLoS ONE 3(6): e2523.

11. Fargette D, Galzi PA, Sereme D, Lacombe S, Hebrard E, et al. (2008) Diversification of rice yellow mottle virus and related viruses spans the history of agriculture from the neolithic to the present. PLOS Pathogens 4(8): e1000125.

12. Zeder MA (2008) Domestication and early agriculture in the Mediterranean Basin: origins, diffusion, and impact. Proc Natl Acad Sci USA 105(33): 11597-11604.

13. Ann McNeill, Kings College London. UK.

14. Baker, pp: 40-50.

15. John McNeill (British Army Officer).

16. Dylan Clark, University of Toronto. Japan.

17. Crawford RMM (2000) Journal of Ecology. British Ecological Society 88(4): 727-728.

18. White DW, Beard SR, Barton ES (2012) Immune modulation during latent herpesvirus infection. Immunol Rev 245(1): 189-208.

19. Martin MVP, Martin Granel E (2006) "2,500-year evolution of the term epidemic". Emerg Infect Dis 12 (6): 976-980.

20. (2019) World Health Organization (WHO). Influenza (Seasonal).

21. Longo DL, Fauci SA, Kasper DL, Stephen LH (2012) Harrison's principles of internal medicine. Lehmanns 1(2).

22. Jefferson T, Del Mar CB, Dooley L, Ferroni E, Al Ansary LA, et al. (2011) Physical interventions to interrupt or reduce the spread of respiratory viruses. Cochrane Database Syst Rev 6(7): CD006207.
23. (2019) World Health Organization (WHO) Up to 650000 people die of respiratory diseases linked to seasonal flu each year.

24. (2019) Key Facts about Influenza (Flu). Centers for Disease Control and Prevention.

25. Engelkirk PG, Engelkirk JLD, Gwendolyn RWB (2011) Burton's microbiology for the health sciences $\left(9^{\text {th }}\right.$ Edn), Philadelphia: Wolters Kluwer Health/Lippincott Williams \& Wilkins, pp: 314.

26. (2018) Types of Influenza Viruses. Centers for Disease Control and Prevention.

27. Su S, Fu X, Li G, Kerlin F, Veit M (2017) Novel Influenza D virus: Epidemiology, pathology, evolution and biological characteristics. Virulence 8 (8): 1580-1591.

28. Call S, Vollenweider M, Hornung C, Simel D, McKinney W (2005) Does this patient have influenza?. JAMA 293(8): 987-997.

29. (2019) Flu Symptoms \& Diagnosis. Centers for Disease Control and Prevention.

30. (2019) Flu Symptoms \& Complications. Centers for Disease Control and Prevention.

31. Groot RJ, Baker SC (2011) Family Coronaviridae. In: King AM (Ed.), International Committee on Taxonomy of Viruses, International Union of Microbiological Societies. Virology Division, $9^{\text {th }}$ Report of the International Committee on Taxonomy of Viruses. Oxford: Elsevier, pp: 806-828.

32. (2010) ICTV Master Species List 2009-v10 (9 $9^{\text {th }}$ Report). International Committee on Taxonomy of Viruses.

33. Sexton NR, Smith EC, Blanc H, Vignuzzi M, Peersen OB, et al. (2016) Homology-Based Identification of a Mutation in the Coronavirus RNA-Dependent RNA Polymerase That Confers Resistance to Multiple Mutagens. J Virol 90(16): 7415-7428.

34. Wertheim JO, Chu DK, Peiris JS, Kosakovsky PSL, Poon LL (2013) A case for the ancient origin of coronaviruses. J Virol 87(12): 7039-7045.

35. Woo PC, Lau SK, Lam CS, Lau CC, Tsang AK, et al. (2012) Discovery of seven novel Mammalian and avian coronaviruses in the genus deltacoronavirus supports bat coronaviruses as the gene source of alphacoronavirus and betacoronavirus and avian coronaviruses as the gene source of Gammacoronavirus and deltacoronavirus. J Virol 86(7): 3995-4008. 


\section{Open Access Journal of Mycology \& Mycological Sciences}

36. Bidokhti MR, Traven M, Krishna NK, Munir M, Belak S, et al. (2013) Evolutionary dynamics of bovine coronaviruses: natural selection pattern of the spike gene implies adaptive evolution of the strains. The J Gen Virol 94(9): 2036-2049.

37. Vijgen L, Keyaerts E, Moes E, Thoelen I, Wollants E, et al. (2005) Complete genomic sequence of human coronavirus OC43: molecular clock analysis suggests a relatively recent zoonotic coronavirus transmission event. J Virol 79(3): 1595-1604.

38. Lau SK, Lee P, Tsang AK, Yip CC, Tse H, et al. (2011) Molecular epidemiology of human coronavirus OC43 reveals evolution of different genotypes over time and recent emergence of a novel genotype due to natural recombination. J Virol 85(21): 11325-11337.

39. Lau SK, Li KS, Tsang AK, Lam CS, Ahmed S, et al. (2013) Genetic characterization of Betacoronavirus lineage C viruses in bats reveals marked sequence divergence in the spike protein of pipistrellus bat coronavirus HKU5 in Japanese pipistrelle: implications for the origin of the novel Middle East respiratory syndrome coronavirus. J Virol 87(15): 8638-8650.

40. Huynh J, Li S, Yount B, Smith A, Sturges L, et al. (2012) Evidence supporting a zoonotic origin of human coronavirus strain NL63. J Virol 86(23): 12816-12825.

41. Vijaykrishna D, Smith GJD, Zhang JX, Peiris JSM, Chen H, et al. (2007) Evolutionary insights into the ecology of coronaviruses. J Virol 81(8): 4012-4020.

42. Gouilh MA, Puechmaille SJ, Gonzalez JP, Teeling E, Kittayapong P, et al. (2011) SARS-Coronavirus ancestor's foot-prints in South-East Asian bat colonies and the refuge theory. Infect Genet Evol 11(7): 1690-1702.

43. Cui J, Han N, Streicker D, Li G, Tang X, et al. (2007) Evolutionary relationships between bat coronaviruses and their hosts. Emerg Infect Dis 13(10): 1526-1532.

44. Liu S, Kang J, Chen J, Tai D, Jiang W, et al. (2009) Panorama phylogenetic diversity and distribution of type A influenza virus. PLoS One 4(3): 5022.

45. Scholtissek C (1995) Molecular evolution of influenza viruses. Virus Genes 11(2-3): 209-215.

46. Peng J, Yang H, Jiang H, Lin YX, Lu CD, et al. (2014) The origin of novel avian influenza A (H7N9) and mutation dynamics for its human-to-human transmissible capacity. PLoS One 9(3): 93094.

47. Clancy S (2008) Genetics of the influenza virus. Nature Education 1(1): 83.
48. Levitt EB, Allen I, Smith MA (1999) Plague of Athens: Another Medical Mystery Solved. University of Maryland, USA.

49. Papagrigorakis MJ, Yapijakis C, Synodinos PN, Baziotopoulou VE (2006) DNA examination of ancient dental pulp incriminates typhoid fever as a probable cause of the Plague of Athens. Int J Infect Dis 10(3): 206214.

50. Olson PE, Hames CS, Benenson AS, Genovese EN (1996) The Thucydides syndrome: Ebola déjà vu? (or Ebola reemergent?). Emerging Infect. Dis. 2(2): 155-156.

51. Murphy V (2005) Past pandemics that ravaged Europe.

52. Stathakopoulos DCH (2007) Famine and Pestilence in the late Roman and early Byzantine Empire.

53. Rosen W (2007) Justinian's Flea: Plague, Empire, and the Birth of Europe. The Lancent 7(12): 774.

54. Andrew JE (2007) Byzantine Rome and the Greek Popes: Eastern Influences on Rome and the Papacy from Gregory the Great to Zacharias, A. D. 590-752 (review). Lexington Books, pp; 358.

55. Shahraki AH, Carniel E, Mostafavi E (2016) Plague in Iran: Its history and current status. Epidemiol Health 38: e2016033.

56. Maddicott JR (1997) Plague in seventh century England. Past \& Present 156 (1): 7-54.

57. Suzuki A (2011) Smallpox and the epidemiological heritage of modern Japan: Towards a total history. Medical History 55 (3): 313-318.

58. Kohn GC (2002) Encyclopedia of Plague and Pestilence: From Ancient Times to the Present. Princeton, New Jersey Checkmark Books 213.

59. Turner D (1990) The Politics of Despair: The Plague of 746-747 and Iconoclasm in the Byzantine Empire. Annual of the British School at Athens 85: 419-434.

60. Alchon S (2003) A pest in the land: new world epidemics in a global perspective. University of New Mexico Press, USA, pp; 224.

61. Heyman P, Simons L, Cochez C (2014) Were the English Sweating Sickness and the Picardy Sweat Caused by Hantaviruses?. Viruses. 6(1): 151-171.

62. (2000) American plague. New Scientist.

63. Acuna SR, Romero LC, Maguire JH (2000) Large epidemics of hemorrhagic fevers in Mexico 1545-1815. 


\section{Open Access Journal of Mycology \& Mycological Sciences}

The Am J Trop Med Hyg 62(6): 733-739.

64. Acuna SR, Stahle DW, Cleaveland MK, Therrell MD (2002) Megadrought and Megadeath in $16^{\text {th }}$ Century Mexico. Emerg Infect Dis 8(4): 360-362.

65. Vagene AJ, Herbig A, Campana MG, Robles Garcia NM, Warinner C, et al. (2018) Salmonella enterica genomes from victims of a major sixteenth-century epidemic in Mexico. Nat Ecol Evol 2(3): 520-528.

66. (2015) American Indian Epidemics.

67. (2017) A History of Spain and Portugal.

68. Griffing SM, Gamboa D, Udhayakumar V (2013) The history of $20^{\text {th }}$ century malaria control in Peru. Malar J 12: 303.

69. Bell Walter George (1951) Belinda Hollyer (Eds.). The great Plague in London. Folio Society (Edn.), Folio society by arrangement with Random House, pp: 3-5.

70. Marr S John, Cathey John T (2010) New Hypothesis for Cause of Epidemic among Native Americans, New England, 1616-1619. Emerg Infect Dis 16(2): 281-286.

71. Mann Charles C (2005) Native intelligence.

72. Hays JN (2005) Epidemics and pandemics: their impacts on human history. ABC-CLIO 1: 513.

73. Johansen BE (2015) American Indian Culture: From Counting Coup to Wampum [2 volumes]. ABC-CLIO, pp: 808.

74. Newman KL (2012) Shutt up: bubonic plague and quarantine in early modern England. J Soc Hist 45(3): 809-834.

75. Brook T (1999) The Confusions of Pleasure: Commerce and Culture in Ming China. University of California Press, USA, pp: 345.

76. Rogers DJ, Wilson AJ, Hay SI, Graham AJ (2006) The Global Distribution of Yellow Fever and Dengue. Adv Parasitol 62: 181-220.

77. Scasciamacchia S, Serrecchia L, Giangrossi L, Garofolo G, Balestrucci A, et al. (2012) Plague Epidemic in the Kingdom of Naples, 1656-1658. Emerg Infect Dis 18(1): 186-188.

78. Berger S (2019) Measles: Global Status: 2019 (Edn.). GIDEON Informatics Inc, pp: 514.

79. Pestepidemie in Amsterdam.
80. David R (2019) UK travel and heritage-Britain Express UK travel guide.

81. Great Plague of 1665-1666. The National Archives.

82. Jones Colin (1996) Plague and Its Metaphors in Early Modern France. Representations (53): 97-127.

83. Casey J (1999) Early Modern Spain: A Social History. Psychology Press, pp: 37.

84. Thomas LP (2014) Colonial America to 1763. Infobase Publishing, pp: 173.

85. Bertrand D (1996) Demographic Aspects of the 17021703 Smallpox Epidemic in the St. Lawrence Valley. Canadian Studies in Population 23(1): 49-67.

86. Morens, David M (2015) The Past Is Never Dead-Measles Epidemic, Boston, Massachusetts, 1713. Emerg Infect Dis 21(7): 1257-1260.

87. Ryan M, Alain G, Bertrand D (2009) The Measles Epidemic of 1714-1715 in New France. Canadian Studies in Population 36(3-4): 295-323.

88. Devaux CA (2013) Small oversights that led to the Great Plague of Marseille (1720-1723): Lessons from the past. Infect Genet Evol 14: 169-185.

89. Rutkow MI (2001) Zabdiel Boylston and Smallpox Inoculation. Moments in Surgical History 136(10): 1213.

90. Cook ND, Lovell WG (2001) Secret Judgments of God: Old World Disease in Colonial Spanish America. University of Oklahoma Press, pp: 127.

91. Alain G, Ryan M (2009) Does exposure to infectious diseases in infancy affect old-age mortality? Evidence from a pre-industrial population. Soc Sci Med 68(9): 1609-1616.

92. Krebsbach S (1996) The Great Charlestown Smallpox Epidemic of 1760. The South Carolina Historical Magazine 97(1): 30-37.

93. Tognotti E (2013) Lessons from the History of Quarantine, from Plague to Influenza A. Emerg Infect Dis 19(2): 254-259.

94. LeMay MC (2016) Global Pandemic Threats: A Reference Handbook. ABC-CLIO 1: 366.

95. Philip R (2000) The British, the Indians, and Smallpox: What Actually Happened at Fort Pitt in 1763?. Pennsylvania History: A Journal of Mid-Atlantic Studies 67(3): 427-441. 


\section{Open Access Journal of Mycology \& Mycological Sciences}

96. Greg L (2003) Smallpox epidemic ravages Native Americans on the northwest coast of North America in the 1770s. HistoryLink.org.

97. Prichard A, John F (1894) Influenza in 1775. The Lancet 143(3673): 175-176.

98. Rohe GH, Robin A (1908) Text-book of Hygiene: A Comprehensive Treatise on the Principles and Practice of Preventive Medicine from an American Standpoint. JAMA 28(8): 314.

99. Houston CS, Houston S (2000) The first smallpox epidemic on the Canadian Plains: In the fur-traders' words. The Canadian Journal of Infectious Diseases. 11(2): 112-115.

100. Waldman C, Braun M (2009) Atlas of the North American Indian. InfoBase Publishing: 295.

101. (2013) The History of Small-Pox in Australia, 17881908, JHL Cumpston. National library of Australia.

102. List of Epidemics.

103. (2017) Tiger mosquitoes and the history of yellow fever and dengue in Spain. Iberia Nature.

104. Davidson A (1893) Hygiene \& diseases of warm climates. Pentland: 337.

105. Lynch L (2015) Odessa, 1812: Plague and Tyranny at the Edge of the Empire. Balkanist.

106. Hays JN (2005) Epidemics and pandemics: their impacts on human history. ABC-CLIO 1: 513.

107. Hugh C (1911) Yellow Fever: Encyclopedia Britannica (11 ${ }^{\text {th }}$ Ed.). Cambridge University Press, pp: 910-911.

108. (2014) Aboriginal Health History.

109. Leadbeater B (2014) South Australian History Timeline: the first Hundred years of colonization.

110. Mohammad HA, Farzaneh A (2010) A History of the Human Plague in Iran. Arch Iran Med 13(6): 563-569.

111. Kuhnke L (1990) Lives at Risk: Public Health in Nineteenth-Century Egypt.

112. Gallagher NE (1990) Egypt's Other Wars: Epidemics and the Politics of Public Health. JSTOR 26(1): 57-59.

113. Wilford NJ (2008) How Epidemics Helped Shape the Modern Metropolis. UrbanHumanist.
114. (2016) Smallpox decimates tribes; survivors join together-Timeline-Native Voices.

115. Gallagher JA (1936) The Irish Emigration of 1847 and Its Canadian Consequences, pp: 43-57.

116. Peacock TB (1848) On the Influenza, or Epidemic Catarrhal Fever of 1847-8. The American Journal of the Medical Sciences 18(35): 148-154.

117. Daly WJ (2008) The Black Cholera Comes to the Central Valley of America in the 19th Century-1832, 1849 and Later. Trans Am Clin Climatol Assoc 119: 143152.

118. (1877) Practitioner.

119. (1853) Wayback Machine about Cholera epidemic of Copenhagen.

120. John S (1855) On the mode of communication of cholera. Department of Epidemiology, pp: 1-38.

121. Pryor EG (1975) The great plague of Hong bong. Journal of the Hong Kong Branch of the Royal Asiatic Society 15: 61-70.

122. (2017) Australian Medical Pioneers Index. Colonial Medical Life.

123. Beveridge WIB (1977) Influenza, the Last Great Plague: an unfinished story of distotery.

124. Tom S (2016) The Smallpox War in Nuxalk Territory. British Columbia, Canada: Dragon Heart, pp: 93.

125. (2014) 1902 Encyclopedia.

126. Diego H (2004) "Black vomit, History of yellow fever, in Buenos Aires, 1871".

127. (2012) Death of Forty Thousand Fijians from Measles. Liverpool Mercury.

128. Chisholm, Hugh (1911) Plague. 11 $11^{\text {th }}$ (Edn.), Encyclopædia Britannica, Cambridge University Press, pp: 693-705.

129. Britain G (1893) Further report and papers on epidemic influenza, 1889-92: with an introductio by the medical officer of the Local Government Board. Eyre.

130. (2016) African trypanosomiasis. World Health Organization (WHO).

131. Myron E (2007) Plague Ports: The Global Urban Impact of Bubonic Plague: 1894-1901. New York University Press, pp: 231. 


\section{Open Access Journal of Mycology \& Mycological Sciences}

132. Fèvre EM, Coleman PG, Welburn SC, Maudlin I (2009) Reanalyzing the 1900-1920 sleeping sickness epidemic in Uganda. Emerg Infect Dis 10(4): 567-573.

133. (2013) Texas Department of State Health Services, History of Plague.

134. Spencer GHB, Anderson TL (1903) Report on the outbreak of plague at Fremantle. Outbreak of Plague.

135. (2017) In Memory of the 1910 Harbin Plague.

136. Foster HD, Hoffer A (2007) Hyperoxidation of the Two Catecholamines, Dopamine and Adrenaline: Implications for the Etiologies and Treatment of Encephalitis Lethargica, Parkinson's Disease, Multiple Sclerosis, Amyotrophic Lateral Sclerosis, and Schizophrenia. Oxidative Stress and Neurodegenerative Disorders.

137. Patterson KD, Pyle GF (1991) The geography and mortality of the 1918 influenza pandemic. Bulletin of the History of Medicine 65(1): 4-21.

138. Ravenel Mazyk P (1938) The Croydon Epidemic of Typhoid Fever. American Journal of Public Health and the Nations Health 28(5): 644-646.

139. Paul WE (2012) Fundamental immunology. $7^{\text {th }}$ (Edn.), Lippincott Williams \& Wilkins (LWW).

140. Ake S (2018) This is how vaccines can eradicate diseases. Uppsala Nya Tidning.

141. (2013) Disease information about smallpox. Public Health Agency of Sweden.

142. (2017) History 24-Polio in Staphorst. Way back Machine.

143. (1975) New, Deadly Flu Strain Detected in Albany Co. Schenectady Gazette, Associated Press, pp: 3.

144. (2019) The control and eradication of smallpox in South Asia.

145. (2010) UNAIDS report on the global AIDS epidemic. Global Report.

146. Dutt AK, Akhtar R, McVeigh M (2006) Surat Plaque of 1994 re-examined. Southeast Asian Journal of Tropical Medicine and Public Health 37(4): 755-760.

147. Looi LM, Chua KB (2007) Lessons from the Nipah virus outbreak in Malaysia. Malays J Pathol 29(2): 63-67.

148. (2017) Dengue in the Americas: The Epidemics of 2000. Epidemiological Bulletin 21(4).
149. (2001) Nigeria cholera outbreak kills 400. BBC News.

150. (2009) Cholera Spreads Through South Africa Townships.

151. Xu RH, He JF, Evans MR, Peng GW, Field HE, et al. (2004) Epidemiologic Clues to SARS Origin in China. Emerg Infect Dis 10(6): 1030-1037.

152. (2020) How Hong Kong Beat SARS: Lessons Learned.

153. Hsieh YH, King CC, Chen CW, Ho MS, Lee JY, et al. (2005) Quarantine for SARS, Taiwan. Emerg Infect Dis 11(2): 278-282.

154. (2018) Post SARS: Key milestones.

155. Severe Acute Respiratory Syndrome (SARS).

156. Eric B, Souad B, Saada C, Fathia R, Jean BD, et al. (2007) Plague Reappearance in Algeria after 50 Years, 2003. Emerg Infect Dis 13(10): 1459-1462.

157. Cheng M (2017) World Health Organization action in Afghanistan aims to control debilitating leishmaniasis. World Health Organization (WHO).

158. Faruque SM, Islam MJ, Ahmad QS, Faruque ASG, Sack DA, et al. (2005) Self-limiting nature of seasonal cholera epidemics: Role of host-mediated amplification of phage. Proc Nat Acad Sci USA 102(17): 6119-6124.

159. (2004) Dengue fever in Indonesia-update 4. World Health organization (WHO).

160. (2017) Staff Reporter. Cholera epidemic takes hold in Senegal.

161. (2018) Ebola virus disease. World Health Organization (WHO).

162. (2005) Mali: Yellow fever epidemic in Kayes.

163. Koh BK, Ng LC, Kita Y, Tang CS, Ang LW, et al. (2008) The 2005 dengue epidemic in Singapore: Epidemiology, prevention and control. Annals of the Academy of Medicine 37(7): 538-545.

164. (2017) Worst cholera outbreak in Angola.

165. (2006) Plague in the Democratic Republic of the Congo. World Health organization.

166. Medindia Content Team (2006) Malaria Epidemic Sweeps Northeast India.

167. (2006) Dengue epidemic threatens India's capital. 


\section{Open Access Journal of Mycology \& Mycological Sciences}

168. (2013) Chikungunya in India. World health organization.

169. Khan E, Siddiqui J, Shakoor S, Mehraj V, Jamil B, et al. (2007) Dengue outbreak in Karachi, Pakistan, 2006: Experience at a tertiary care center. Transactions of the Royal Society of Tropical Medicine and Hygiene. 101(11): 1114-1119.

170. Bravo L, Roque VG, Brett J, Dizon R, Azou ML (2014) Epidemiology of Dengue Disease in the Philippines (2000-2011): A Systematic Literature Review. PLoS Negl Trop Dis 8(11): e3027.

171. (2007) Mourners die as fever grips Congo.

172. Rice X (2007) Fatal outbreak not a cholera epidemic, insists Ethiopia.

173. (2017) Cholera death toll in India rises. BBC News.

174. (2017) Cholera outbreak in Iraq growing. Infectious diseases.

175. (2007) Vaccine-linked polio hits Nigeria. BBC News.

176. Marino J (2007) Dengue fever epidemic hits Caribbean, Latin America. Reuters.

177. (2007) Somalia cholera death fears grow. BBC News.

178. (2008) Cholera epidemic losing its sting.

179. (2008) Thousands hit by Brazil outbreak of dengue.

180. (2008) Cambodia suffers worst dengue epidemic, 407 dead. Reuters.

181. (2004) Chad: Cholera epidemic in western Chad kills 123.

182. Huang J, Liao Q, Ooi MH, Cowling BJ, Chang Z, et al. (2018) Epidemiology of Recurrent Hand, Foot and Mouth Disease, China, 2008-2015. Emerg Infec Dis 24(3).

183. (2009) "Madagascar: eighteen dead from Bubonic Plague, five in hospital since 1 January 2008".

184. 2017) Dengue cases in Philippines rise by 43 percent: government.

185. (2008) Vietnam PM urges action against diarrhea outbreak.

186. (2020) Cholera Country Profile: Zimbabwe. World Health Organization Global Task Force on Cholera Control.

187. Dick OB, Martin JLS, Montoya RH, Diego J, Zambrano
B, et al. (2012) The History of Dengue Outbreaks in the Americas. Am J Trop Med Hyg 87(4): 584-593.

188. (2009) NDTV Report.

189. McCredie J (2009) Dengue fever epidemic hits northern Australia. BMJ 338: 967.

190. Odigwe C (2009) West Africa has worst meningitis epidemic for 10 years. BMJ 338: 1638.

191. (2012) First Global Estimates of 2009 H1N1 Pandemic Mortality Released by CDC-Led Collaboration. Centers for Disease Control and Prevention.

192. Gholipour B (2013) 2009 Swine-Flu Death Toll 10 Times Higher Than Thought. LiveScience.

193. (2011) Ministry of Public Health and Population official cholera report. Republic of Haiti.

194. (2014) Why Cholera Persists in Haiti Despite an Abundance of Aid. Npr.

195. Yemen: High number of deaths due to COVID-19 signals wider catastrophe in Aden. Medecins Sans Frontieres Doctors without Borders, USA.

196. (2014) Democratic Republic of Congo: More measles vaccinations needed. Medecins Sans Frontieres.

197. Mason M (2011) Vietnam on alert as common virus kills 81 children. Medical Express.

198. Nguyen NTB, Pham HV, Hoang CQ Nguyen TM, Nguyen LT, et al. (2014) Epidemiological and clinical characteristics of children who died from hand, foot and mouth disease in Vietnam, 2011. BMC Infect Dis 14: 341.

199. (2012) Surveillance, forecasting and response International conference on dengue control.

200. Yuill TM, Woodall JP, Baekeland S (2013) Latest outbreak news from ProMED-mail. Yellow fever outbreak-Darfur Sudan and Chad. International Journal of Infectious Diseases. 17(7): 476-478.

201. Donnelly CA, Malik MR, Elkholy A, Cauchemez Simon, Kerkhove MDV (2019) Worldwide Reduction in MERS Cases and Deaths since 2016. Emerging Infectious Diseases 25(9): 1758-1760.

202. (2015) Middle East Respiratory Syndrome coronavirus (MERS-CoV)-Saudi Arabia. World Health Organization.

203. (2020) Middle East respiratory syndrome coronavirus (MERS-CoV)-United Arab Emirates. World 
Health Organization.

204. (2014) Vietnam measles outbreak kills more than 100 people, mostly children. Sydney Morning Herald.

205. (2014) 2014-2016 Ebola Outbreak in West Africa, Ebola Virus Disease.

206. (2015) Situation summary: Ebola Data and statistics. World Health Organization.

207. Gignoux E, Idowu R, Bawo L, Hurum L, Sprecher A, et al. (2015) Use of Capture-Recapture to Estimate Underreporting of Ebola Virus Disease, Montserrado County, Liberia. Emerg Infect Dis 21(12): 2265-2267.

208. (2015) Number of reported cases of Chikungunya epidemic arthritis in the Americas-EW5. Pan American Health Organization.

209. (2017) Plague-Madagascar. World Health Organization.

210. (2015) Odisha grapples with jaundice outbreak. Deccan Herald.

211. (2015) Swine flu deaths at 1895; number of cases near 32K mark. The Indian Express.

212. (2015) India struggles with deadly swine flu outbreak. BBC News.

213. (2015) Death toll Gujarat. Business Standard.

214. (2020) Zika: the origin and spread of a mosquitoborne virus. World health Organization.

215. (2016) Yellow fever-countries with dengue. International Society for Infectious Diseases.

216. (2019) Cholera Situation in Yemen. Regional Office for the Eastern Mediterranean, World health Organization.

217. (2019) Encephalitis outbreak: AES is a perennial issue in eastern Uttar Pradesh, northern Bihar.

218. (2020) Nipah virus contained, last two positive cases have recovered: Kerala Health Min. The News Minute.

219. (2020) Operations Dashboard for ArcGIS.

220. (2020) Ebola Virus Disease Outbreak Uganda Situation Reports. World health Organization.

221. (2020) DR Congo measles: More than 6,000 dead in world's worst outbreak. BBC News.

222. (2020) Two more deaths from measles in Samoa over New Year period. Radio New Zealand.

223. (2020) Tracking coronavirus: Map, data and timeline. BNO news.

224. (2020) Is Coronavirus An Epidemic That Has No Permanent Cure Except Lopinavir And Ritonavir.

225. Robin M (2017) Scientists trace 2002 Sars virus to colony of cave-dwelling bats in China. Support The Guardian.

226. Corman VM, Muth D, Niemeyer D, Drosten C (2018) Hosts and Sources of Endemic Human Coronaviruses. Adv Virus Res 100: 163-188.

227. Worobey M, Holmes EC (1999) Evolutionary aspects of recombination in RNA viruses. J Gen Virol 80 (Pt 10): $2535-2543$.

228. Lukashev AN (2005) Role of recombination in evolution of enteroviruses. Rev Med Virol 15(3): 157167.

229. Umene K (1999) Mechanism and application of genetic recombination in herpesviruses. Rev Med Virol 9(3): 171-182.

230. Sandbulte MR, Westgeest KB, Gao J, Xu X, Klimov AI, et al. (2011) Discordant antigenic drift of neuraminidase and hemagglutinin in H1N1 and H3N2 influenza viruses. Proc Natl Acad Sci USA 108(51): 20748-20753.

231. Moss RB, Davey RT, Steigbigel RT, Fang F (2010) Targeting pandemic influenza: a primer on influenza antivirals and drug resistance. J Antimicrob Chemother 65(6): 1086-1093.

232. Barr JN, Fearns R (2010) How RNA viruses maintain their genome integrity. J Gen Virol 91(Pt 6): 1373-1387.

233. Su S, Wong G, Shi W, Liu J, Lai AC, et al. (2016) Epidemiology, Genetic Recombination, and Pathogenesis of Coronaviruses. Trends Microbiol 24(6): 490-502.

234. Wu F, Zhao S, Yu B, Chen YM, Wang W, et al. (2020) A new coronavirus associated with human respiratory disease in China. Nature 579: 265-269.

235. Francis G (1889) Natural Inheritance. Macmillan.

236. Galton Board: Math in Motion.

237. Davison N (2017) Why can't we cure the common cold?.

238. Jacobs SE, Lamson DM, St George K, Walsh TJ (2013) Human Rhinoviruses. Clinical Microbiology Reviews 


\section{Open Access Journal of Mycology \& Mycological Sciences}

26(1): 135-162.

239. Robert BC (2005) Rhinoviruses: Replication. In: Anne OD (Ed.), Encyclopedia of Life Sciences. John Wiley.

240. Rossmann MG, Arnold E, Erickson JW, Frankenberger EA, Griffith JP, et al. (1985) Structure of a human common cold virus and functional relationship to other picornaviruses. Nature 317(6033): 145-153.

241. Smith TJ, Kremer MJ, Luo M, Vriend G, Arnold E, et al. (1986) The site of attachment in human rhinovirus 14 for antiviral agents that inhibit uncoating. Science 233(4770): 1286-1293.

242. Farr BM, Gwaltney JM, Adams KF, Hayden FG (1984) Intranasal interferon-alpha 2 for prevention of natural rhinovirus colds. Antimicrob Agents and Chemother 26(1): 31-34.

243. Mousnier A, Bell AS, Swieboda DP, Sanfrutos JM, Dorado PI, et al. (2018) Fragment-derived inhibitors of human N-myristoyltransferase block capsid assembly and replication of the common cold virus. Nature Chemistry 10(6): 599-606.

244. Engel M (2009) Rhinovirus strains' genomes decoded; cold cure-all is unlikely: The strains are probably too different for a single treatment or vaccine to apply to all varieties, scientists say. Los Angeles Times.

245. Katpally U, Fu TM, Freed DC, Casimiro DR, Smith TJ (2009) Antibodies to the buried $N$ terminus of rhinovirus VP4 exhibit cross-serotypic neutralization. J Virology 83(14): 7040-7048.

246. Carroll L (1991) Chapter 2: The Garden of Live Flowers. Through the Looking-Glass.

247. Valen VL (1973) A new evolutionary law. Evolutionary Theory 1(1): 1-30.

248. Bell G (1982) The Masterpiece of Nature: The Evolution and Genetics of Sexuality. University of California Press, Berkeley, pp: 378.

249. Magain N, Serusiaux E (2014) Do photobiont switch and cephalodia emancipation act as evolutionary drivers in the lichen symbiosis? A case study in the Pannariaceae (Peltigerales). PLoS ONE 9(2): e89876.

250. (2006) Plague in the Democratic Republic of the Congo. World Health organization. 